\title{
Frontiers in Zoology
}

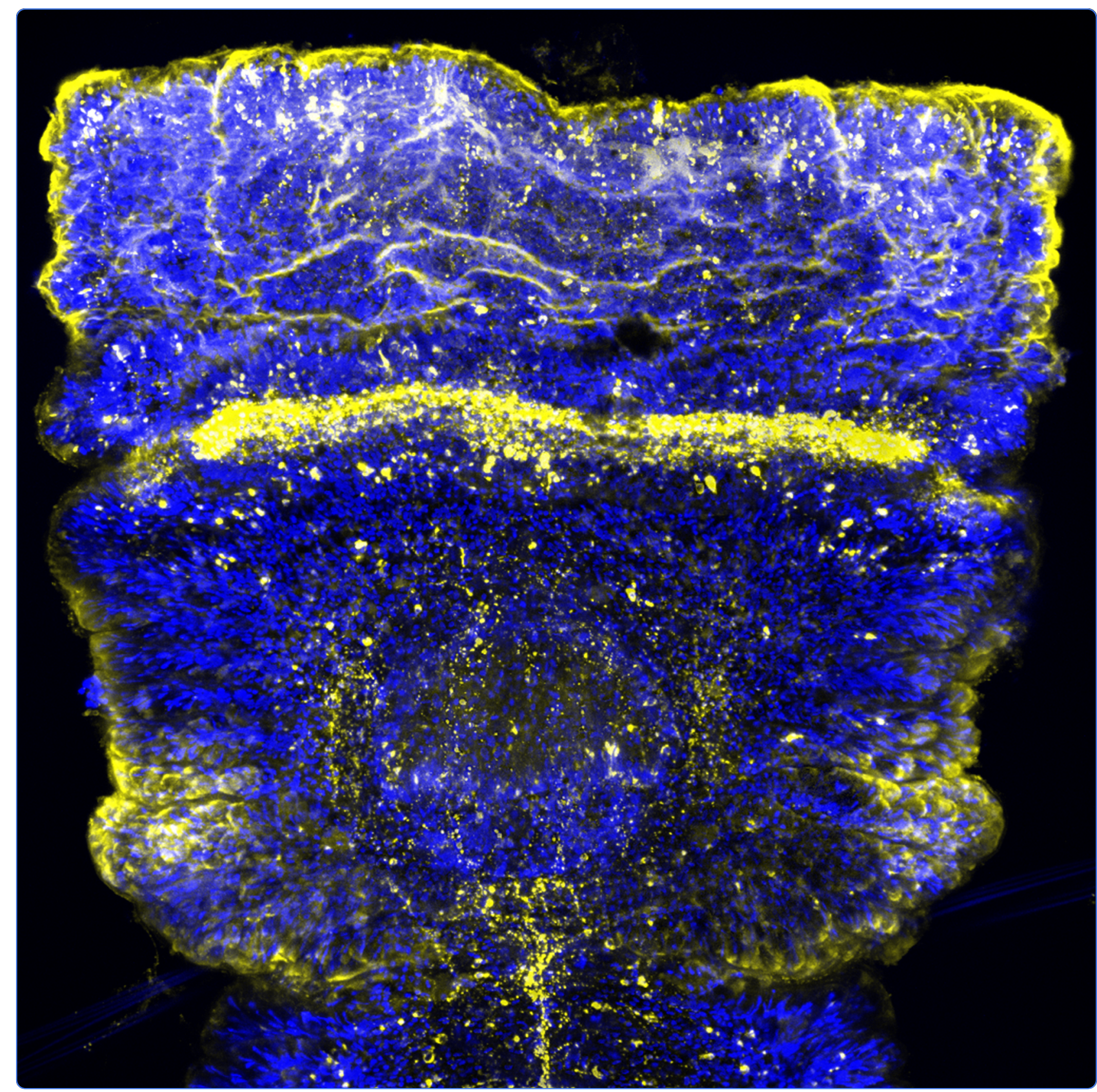

Neural architecture of Galathowenia oculata Zach, 1923 (Oweniidae, Annelida)

Rimskaya-Korsakova et al.

C Biomed Central 


\title{
Neural architecture of Galathowenia oculata Zach, 1923 (Oweniidae, Annelida)
}

Nadezhda N. Rimskaya-Korsakova', Alen Kristof ${ }^{2}$, Vladimir V. Malakhov ${ }^{1}$ and Andreas Wanninger ${ }^{2^{*}}$

\begin{abstract}
Background: Oweniids are marine tubeworms burrowing in muddy sediments that in current phylogenies form an early branching lineage within Annelida. Little is known about their general morphology, in particular the nervous system. Here we provide an immunocytochemical investigation of the nervous system of Galathowenia oculata in order to discuss putative ancestral neuronal features in Oweniidae.

Results: Adult Galathowenia oculata have neither a supraesophageal ganglion nor ganglia associated with the ventral nerve cord. Instead, there is a dorsal brain commissure in the head collar that is engulfed by a cellular cortex. Accordingly, we herein term this neural structure "medullary brain commissure". The anterior margin of the head collar exhibits numerous neurites that emerge from the brain commissure. The dorsolateral folds are innervated by the ventrolateral neurite bundles extending from the circumesophageal connectives. In the anterior uniramous and biramous segments immunoreactive somata are distributed evenly along the ventral nerve cord and arranged metamerically in the posterior-most short segments. One dorsal and two pairs of lateral neurite bundles extend longitudinally along the body. Numerous serially arranged circular neurite bundles were labeled in anteriormost long segments. Metameric arrangement of the circular neurite bundles stained against FMRFamide and acetylated a-tubulin is revealed in posterior short segments. For the first time immunoreactive somata arranged in clusters are reported within the pygidium in oweniids.

Conclusions: Due to the lack of head appendages and a sedentary mode of life, G. oculata exhibits a single dorsal commissure (versus a brain with four commissures in most annelids). A "medullary brain commissure" is known so far only in Oweniidae and Echiura. Lack of ganglia and metamery in the ventral nerve cord of the anteriormost segments might be the result of the elongation of these segments. In the short posterior segments the metamery of immunoreactive somata and circular neurite bundles is conserved. We hypothesize that the unpaired ventral nerve cord in adult oweniids might be a result of an initially paired ventral nerve cord that fuses during development, a condition not uncommon within Annelida.
\end{abstract}

Keywords: Tubulin, Serotonin, FMRFamide, Medullary brain commissure, Medullary nerve cord, Single dorsal commissure, Unpaired ventral nerve cord, Pygidial somata clusters, Dorsolateral folds

\section{Background}

Oweniidae is a small annelid taxon with worldwide distribution from the continental slope to abyssal depths. They live in soft, muddy sediment and are very abundant in the Arctic Seas [1-3]. Currently, 55 valid oweniid species are known [3]. Oweniids deviate from other annelids in a number of morphological and developmental features, having non-typical spiralian embryogenesis [4],

\footnotetext{
* Correspondence: andreas.wanninger@univie.ac.at

${ }^{2}$ Department of Integrative Zoology, University of Vienna, Althanstraße 14,

A-1090 Vienna, Austria

Full list of author information is available at the end of the article
}

a unique mitraria larva with catastrophic metamorphosis $[4,5]$, deuterostome-like larval protonephridia [6], a monociliated epidermis in some species $[7,8]$, absence of a typical annelid-like cuticle $[9,10]$, absence of neuromuscular synapses and control of locomotion through synapses on the surface of the extracellular matrix (ECM) $[11,12]$, as well as the absence of dissepiments separating the segments from each other [13].

The phylogenetic position of oweniids within Annelida is highly debated. Oweniidae was regarded as a taxon closely related to "archiannelids" [14-16], siboglinids $[13,17-20]$, or they were included in one clade together 
with Terebellida, Pogonophora and Sabellida [21]. Later, they were considered to be closest related to Sabellidae [22]. Molecular analyses of $18 \mathrm{~S}$ and $28 \mathrm{~S}$ rDNA sequences suggested a sister group relationship of Owenia fusiformis and Apistobranchus typicus (Apistobranchiidae) [23-25]. According to recent phylogenomic analyses, oweniids are considered one of the early branching annelid taxa, together with Magelonidae, Chaetopteridae, Sipuncula, and Amphinomidae [26-32].

So far, the anatomy of the oweniid nervous system is known mostly from one species, Owenia fusiformis, from histology and electron microscopy [11, 12, 33-37]. These studies revealed several peculiar features in the nervous system, including a single, non-ganglionated ventral nerve cord, a single brain commissure and a varying number of circular neurite bundles depending on segment size.

The present study investigates the morphology of the nervous system of the poorly studied oweniid species Galathowenia oculata (originally described as Myriochele oculata, $[1,13-15,33,34,38,39])$ with immunocytochemical tools that provides data for morphological comparisons of the neural architecture of early branching annelids.

\section{Results}

\section{Gross morphology of Galathowenia oculata}

Galathowenia oculata inhabits slender tubes with two openings built by mud grains. The body of G. oculata is delicate; length and width are up to $30-40 \mathrm{~mm}$ and $0.5 \mathrm{~mm}$, respectively (Fig. 1a). The prostomium and peristomium are fused, forming a head collar with a ventral slit (Fig. 1b). The head collar surrounds a midventral mouth and a ventral pharyngeal organ (Fig. 1c, d, h). Some of our specimens of G. oculata were observed to bear dorsolateral folds on the inner wall of the head collar (Fig. 1d). There are two ventro-lateral, red eyes and a pigmented arch between them in the outer wall of the head collar (Figs. 1b, h, 2a-c). The first three segments are equal in length, short and uniramous, exhibiting only notopodial capillaries (Fig. 1b), while the following 17 to 40 segments vary in length (Fig. 1a). The following nine anteriormost segments (4-12) are long and biramous and have notopodial capillaries and neuropodial uncini (Fig. 1a, e). Posterior segments are shorter, narrower and biramous (Fig. 1a). The posterior-most three to four segments are usually very short $(30-50 \mu \mathrm{m})$, bearing one or two capillaries (Fig. 1g). The pygidium has one dorsal and two ventral lobes (Fig. 1g).

\section{Epidermal ciliation}

The entire epidermis is covered by cilia as revealed by scanning electron microscopy (SEM) and acetylated $\alpha$ tubulin-like immunoreactivity (-lir) (Figs. 1c-d, g, 3a, b, f). The surface of the inner walls of the head collar and the pygidial lobes is heavily ciliated (Fig. 1c, d, g). Additionally, there are several highly ciliated fields throughout the body. One of them overlies the dorsal commissure, a semicircular ciliary band on the dorsal side of the head (see Figs. 1b, 3b), and two lateral ciliary bands extending along the fifth chaetiger (Figs. 1f, 3a).

\section{Glandular fields}

Glandular fields in the epidermis of Galathowenia oculata were revealed by autofluorescence. This was confirmed by ultrastructural data (not shown). Glands are concentrated into a pair of prominent triangular-shaped glandular fields behind the eyes (Fig. 1h). These fields expand backward to the dorso-lateral sides of the uniramous segments. Another two lateral glandular bands extend along the long biramous segments, from the fourth to the seventh, rarely exceeding the anterior part of segment eight (Fig. 1e, f). In the fifth segment, the lateral glandular bands extend along the lateral ciliary bands and together may serve as mucociliary tract (compare Fig. 1e, f). As the ciliary stripes reach the putative nephridal opening at the posterior part of the fifth segment (see Fig. 7h and [15], p.234) it is very likely that they serve excretory functions.

\section{Nervous system architecture}

The central nervous system (CNS) of Galathowenia oculata comprises a dorsal brain commissure, a pair of circumesophageal connectives and a ventral nerve cord (Figs. 2a-c, 3a). The peripheral nervous system (PNS) is represented by five main longitudinal neurite bundles and numerous serially arranged circular neurite bundles that together, with additional longitudinal neurite bundles, form an intraepidermal plexus. The majority of immunocytochemically positive (ICC-positive) somata is scattered along the ventral nerve cord. Parts of the PNS, along with the CNS, lie within the epidermis and include the circular and main longitudinal neurite bundles (Fig. 3d).

\section{Neural elements of the head collar}

Labeling with antibodies against acetylated $\alpha$-tubulin, FMRFamide and serotonin (5HT) equally reveals a loop formed by the dorsal brain commissure and the pair of circumesophageal connectives, the roots of which connect to the ventral nerve cord (Figs. 2a-c, 3a, 4a, 5a). The circumesophageal connectives are connected to numerous transverse commissures (Figs. 2a, b, 3c, 5a). In the head of Galathowenia oculata, numerous ICCpositive somata are present but do not form ganglia (Figs. 2b, c, 4b-d).

Anti-acetylated $\alpha$-tubulin staining visualizes the massive dorsal commissure in the head collar approximately at the level of the eyes (Fig. 3a-c). It is $30 \mu \mathrm{m}$ thick; the neurites within the dorsal commissure are 

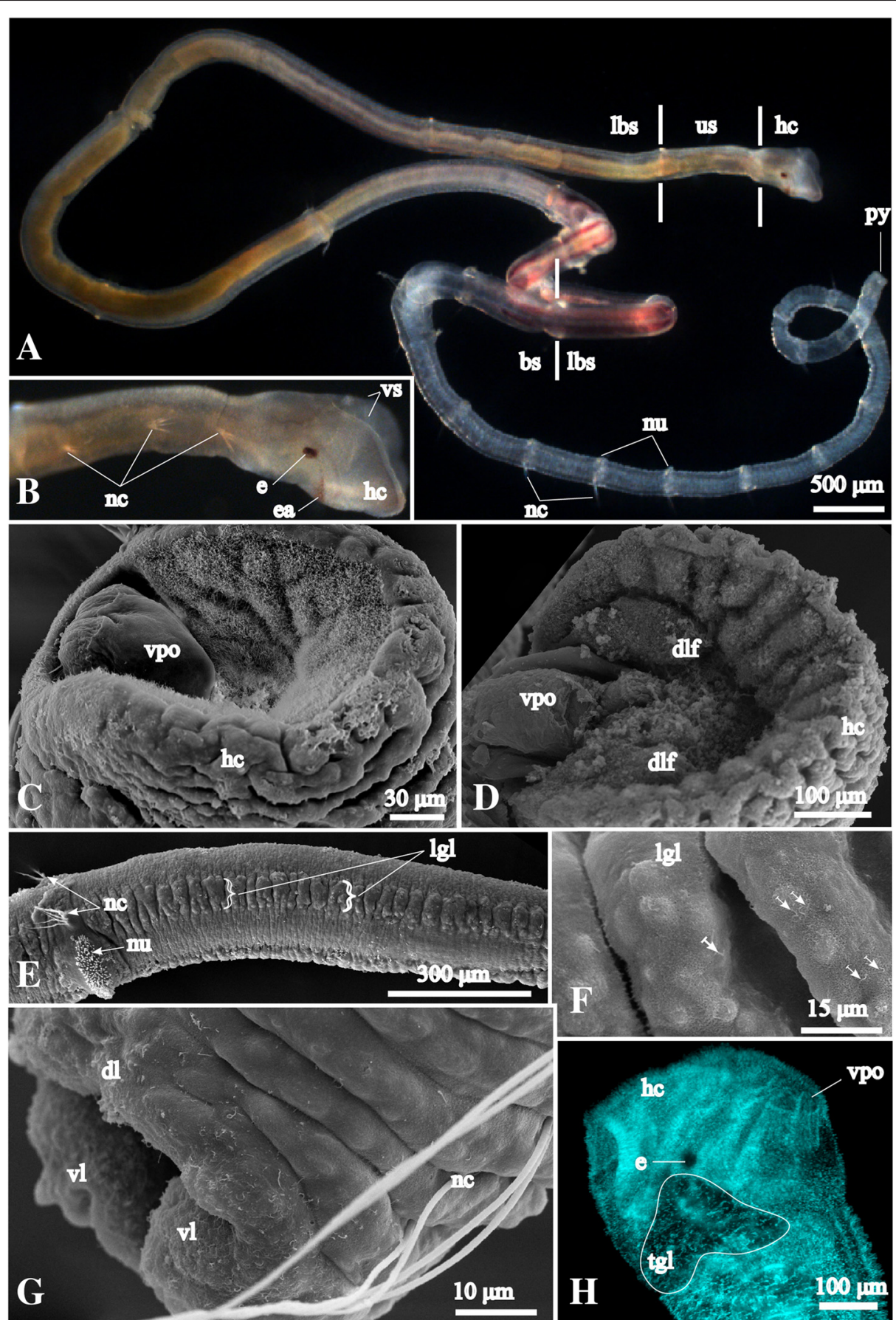

Fig. 1 Gross morphology of Galathowenia oculata. a, b G. oculata without its tube (lateral view, ventral side is up). a Body divided into short uniramous, long biramous and short biramous segments bearing notopodial capillaries and neuropodial uncini. b Head collar with ventral slit, eyes and a pigmented arch between eyes. c, $\mathbf{d}$ Scanning electron micrographs (SEM) of the head collar, ventral side is to the left. The inner part is lined by cilia and bears the ventral pharyngeal organ. Note the variation of the absence (in c) and presence (in $\mathbf{d}$ ) of dorsolateral ciliary folds. e SEM of one of the long biramous segments with the lateral glandular field, anterior end is to the left, ventral side is to the bottom. $\mathbf{f}$ Detail of glandular field with cilia (arrows) and gland papillae (asterisks), orientation as in (e). $\mathbf{g}$ SEM of the posterior-most 4 shortest segments and the pygidium with one dorsal and two ventral lobes, ventral side is to the bottom. $\mathbf{h}$ Nuclei labeling with DAPI (cyan) showing lateral view of head collar with ventral pharyngeal organ and an eye. Note that the absence of the cell nuclei indicates the position of the triangular glandular field. bs - short biramous segments, $d l$ - dorsal pygidial lobe, dlf - dorso-lateral folds, e - eye, ea - pigmented arch between eyes, hc - head collar, $\mid \mathrm{gl}$ - |ateral glandular field, lbs - long biramous segments, nc - notopodial capillaries, nu - neuropodial uncini, py - pygidium, tgl - triangular glandular field, us - short uniramous segments, vl - ventral pygidial lobes, vpo - ventral pharyngeal organ, vs - ventral slit 


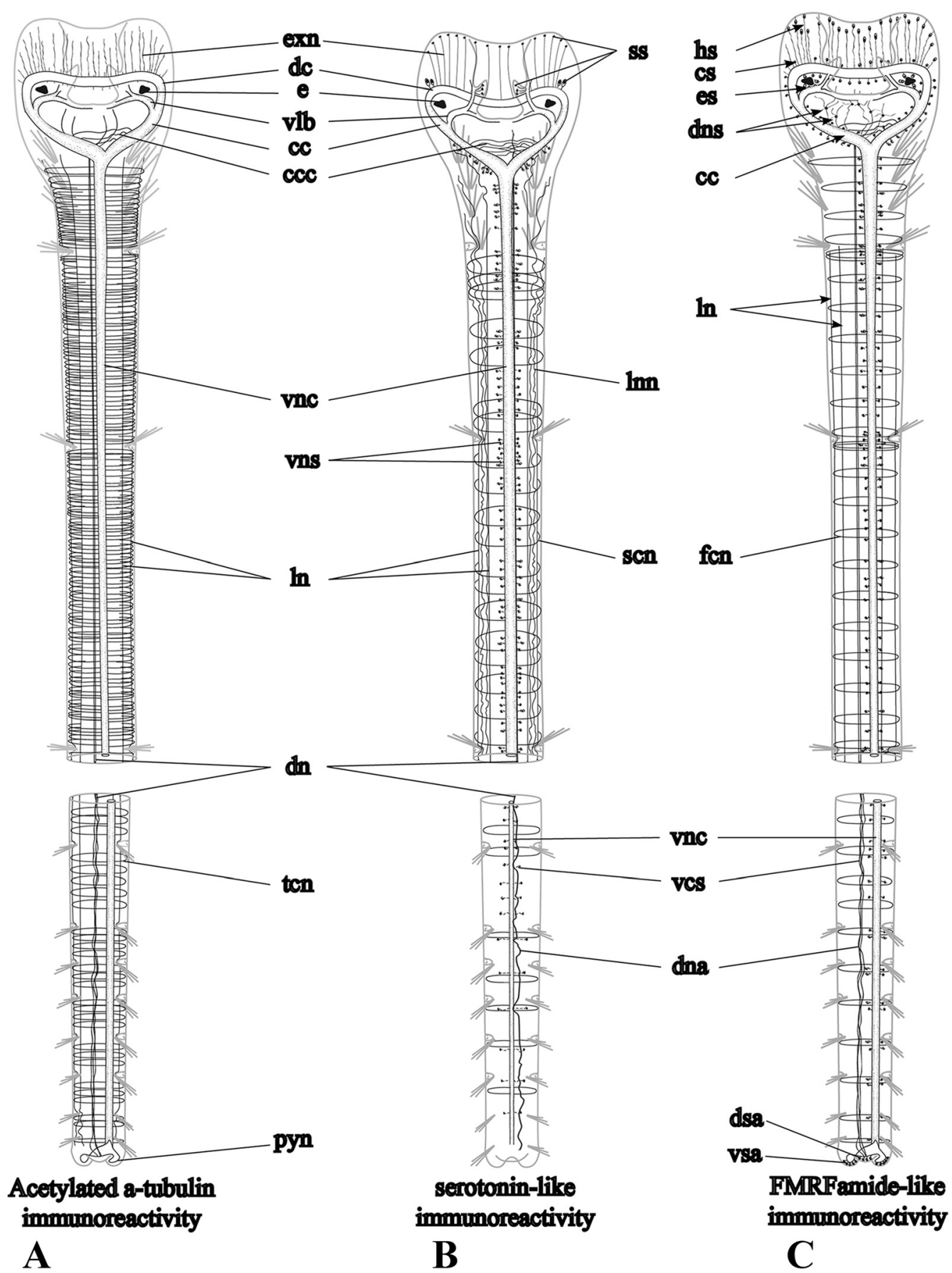

Fig. 2 Schematic drawings of the general organization of the nervous system of Galathowenia oculata. (a) Tubulin-like, (b) serotonin-like and (c) FMRFamide-like immunoreactive nervous systems. Ventral views of anterior and posterior parts, nervous system shown in black, the body wall and chaetae are shown in grey. All three images show the same regions of the specimens, descriptions are given in the text. $c c-c i r c u m e s o p h a-$ geal connectives, $c c c$ - transverse neurites interconnecting $c c, c n$ - serially arranged circular neurite bundles, $d c$ - dorsal commissure, $d n-$ main dorsal neurite bundle, $d n s$ - immunocytochemically (ICC) positive somata associated with the main dorsal neurite bundle in head collar, $d s$ - unipolar FMRFamide-lir somata associated with dorsal commissure, $d s a$ - ICC-positive somata accumulation in dorsal pygidial lobe, e - eye, es - large ICC-positive somata around the eyes, exn - epidermal neurite plexus on outer side of head collar, hs - bipolar FMRFamide-lir somata located in head collar, In - main lateral longitudinal neurite bundles, Inn - lateral neurite plexus between the lateral neurite bundles, pyn - pygidial neurites interconnecting the ventral and dorsal neurite bundles, sc - serotonin-lir cells of collar and dorsolateral folds, ss - serotonin-lir somata, vcs - serotonin-lir somata associated with ventral nerve cord, $v / b$ - ventrolateral neurite bundle in head collar, vnc - ventral nerve cord, vsa - ICC-positive somata accumulations in ventral pygidial lobes 


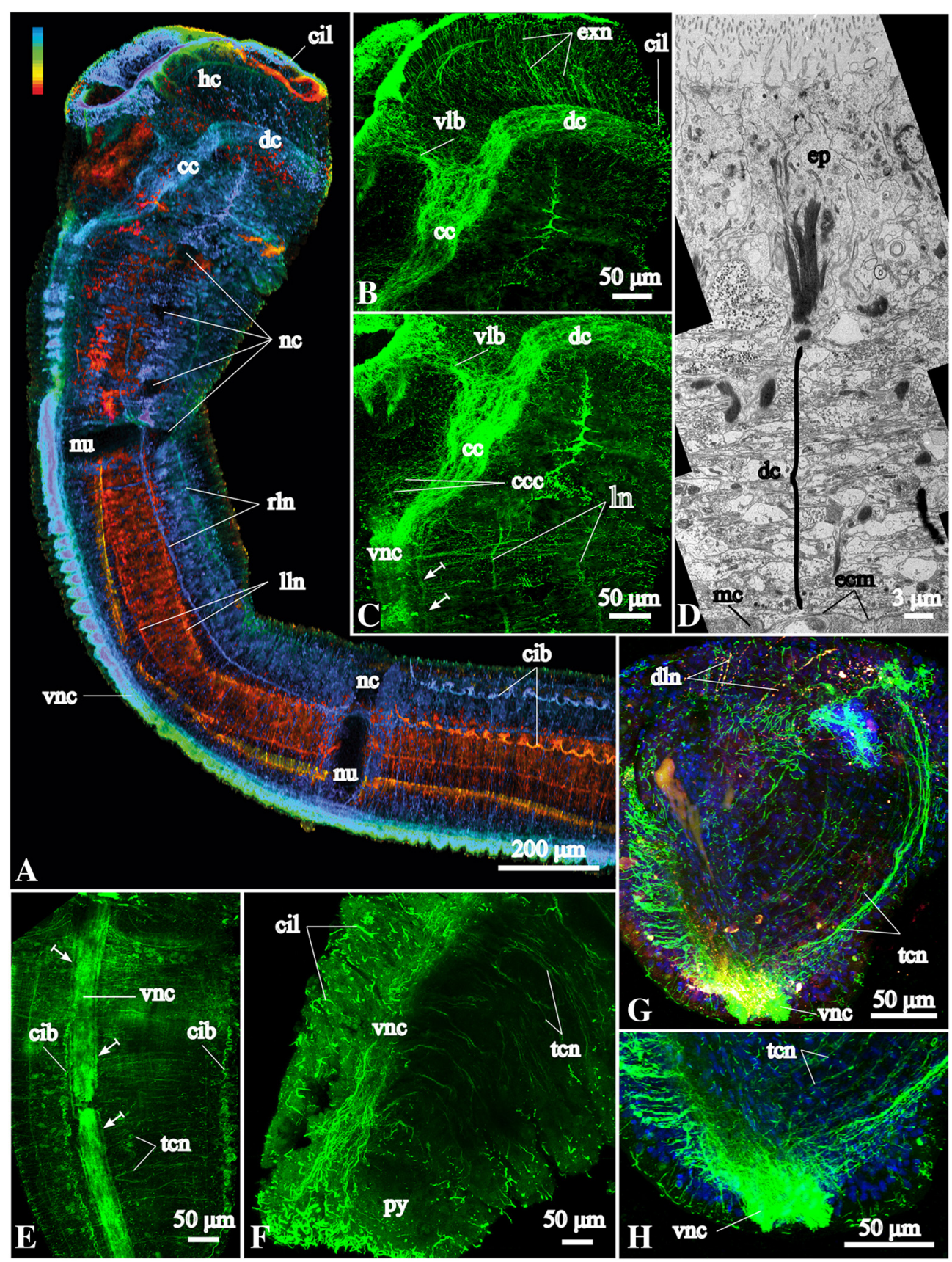

Fig. 3 Tubulin-like immunoreactive (-lir) nervous system architecture in the head region and ultrastructure of the dorsal commissure of Galathowenia oculata. Labeling with antibodies against acetylated a-tubulin (green) and serotonin (red; shown only in $\mathbf{g}$ ); nuclei labeling with DAPI (blue). Maximum projections and whole-amount specimens (a-c, e-h). TEM micrograph (d). a Color-coded image of the tubulin-lir dorsal commissure, ventral nerve cord and two pairs of the main peripheral longitudinal neurite bundles, lateral view, ventral side is to the left. $\mathbf{b}$, $\mathbf{c}$ Lateral views show the nervous system within the head, note the collateral neurite bundles along the ventral nerve cord (arrows), ventral side is to the left. d Intraepidermal neurite bundles of the dorsal commissure (shown by bracket), transverse section of the head collar. e Tubulin-lir ventral nerve cord with collateral neurite bundles (arrows), trunk region; dorsal view, anterior is to the top. $\mathbf{f}$ Tubulin-lir ventral nerve cord in the posterior-most segments and pygidium, note cilia covering the surface, ventral side is to the top. $\mathbf{g}$, $\mathbf{h}$ Tubulin-lir and serotonin-lir (in $\mathrm{G}$ ) and only tubulin-lir (in $\mathrm{H}$ ) ventral nerve cord with numerous serially arranged circular neurite bundles: transverse section of trunk region, note the paired structure of the nerve cord, ventral side is to the bottom. $c c$ - circumesophageal connectives, ccc - neurites interconnecting cc, cib - ciliary band, cil - cilia, $d c$ - dorsal commissure, dln main dorsolateral neurite bundles, $d n$ - main dorsal neurite bundle, e - eye, ecm - exctracellular matrix, ep - epidermis, exn - epidermal plexus within the outer side of $h c, h c$ - head collar, $m c$ - muscle cells, py - pygidium, tcn - tubulin-lir serially arranged circular neurite bundles, vlb - main ventrolateral neurite bundle, $v n c$ - ventral nerve cord, $v p o$ - ventral pharyngeal organ 


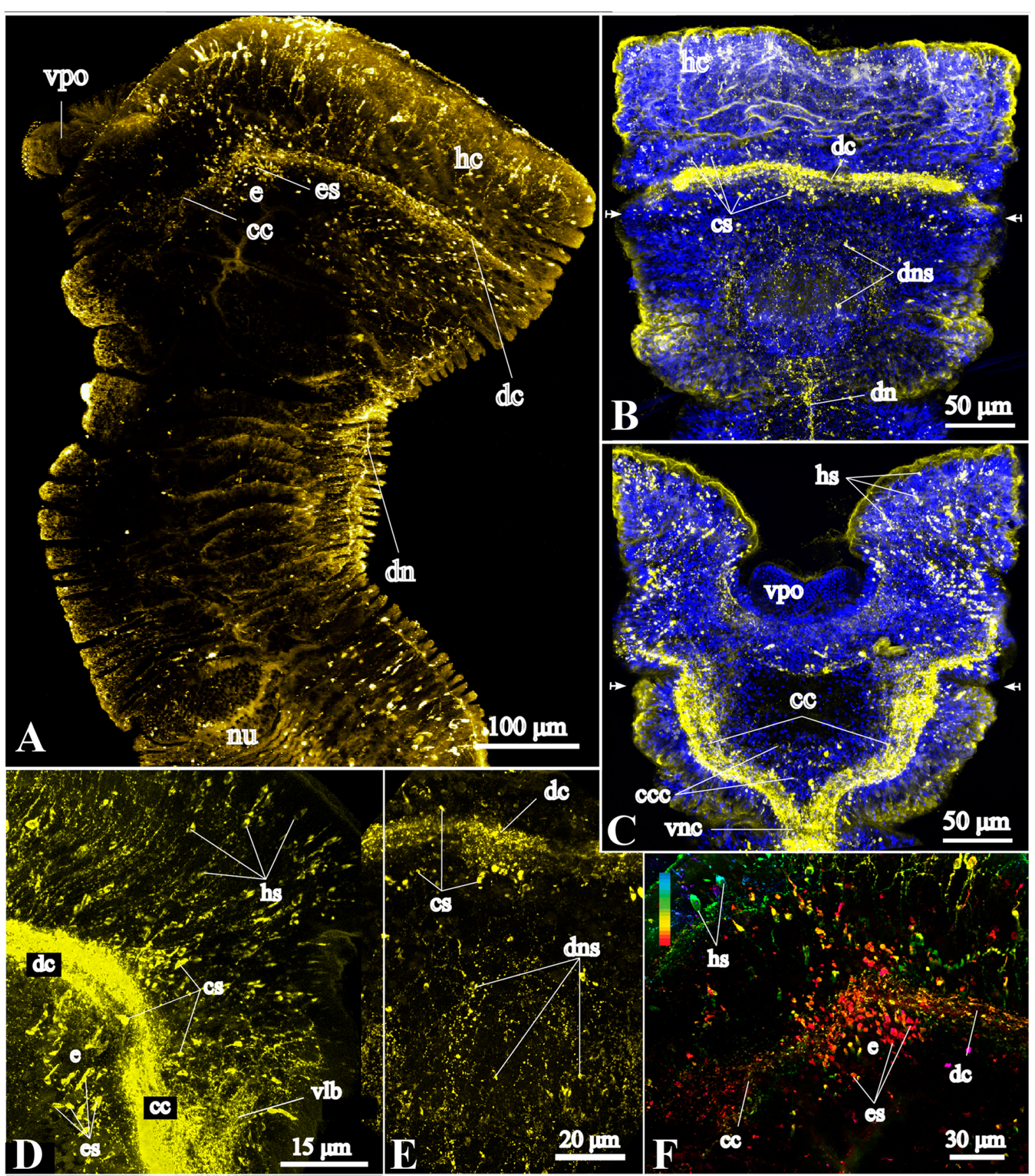

Fig. 4 FMRFamide-like immunoreactive (-lir) nervous system in the head region. Anti-FMRFamide-lir (yellow) and nuclei labeling with DAPI (blue), maximum projections, whole-mount specimens. a Overview of FMRFamide-lir nervous system in the head region and the anterior-most segments, lateral view, ventral side is to the left. b, c FMRFamide-lir neural elements in the head region: the dorsal commissure and the circumesophageal connectives, dorsal and ventral views, respectively. Arrows indicate the position of eyes. e shows precise details of dorsal neural elements. d FMRFamide-lir somata of the head collar, lateral view. Immunocytochemically positive (ICC-positive) somata are distributed along the dorsal commissure within the head collar and around the eyes, ventral side is to the right. e Somata whose processes interconnecting the dorsal commissure and the main dorsal neurite bundle, dorsal view of the head collar (larger view of $\mathbf{b}$ ). $\mathbf{f}$ Color coded image of ICC-positive somata around the eyes, lateral view of the head collar (the same specimen as in a). cc - circumesophageal connectives, ccc - neurites interconnecting $C C, C S$ - ICC-positive somata along the dorsal commissure, $d c$ - dorsal commissure, $d n$ - main dorsal neurite bundle, dns - ICC-positive somata whose processes interconnect $d c$ and $d n, e$ - eye, es - large ICC-positive somata around the eyes, $h c$ - head collar, $h s$ - ICC-positive somata located in the epidermis of the anterior head region, $v / b$ - main ventrolateral neurite bundle, $v n c$ - ventral nerve cord, $v p o$ - ventral pharyngeal organ 


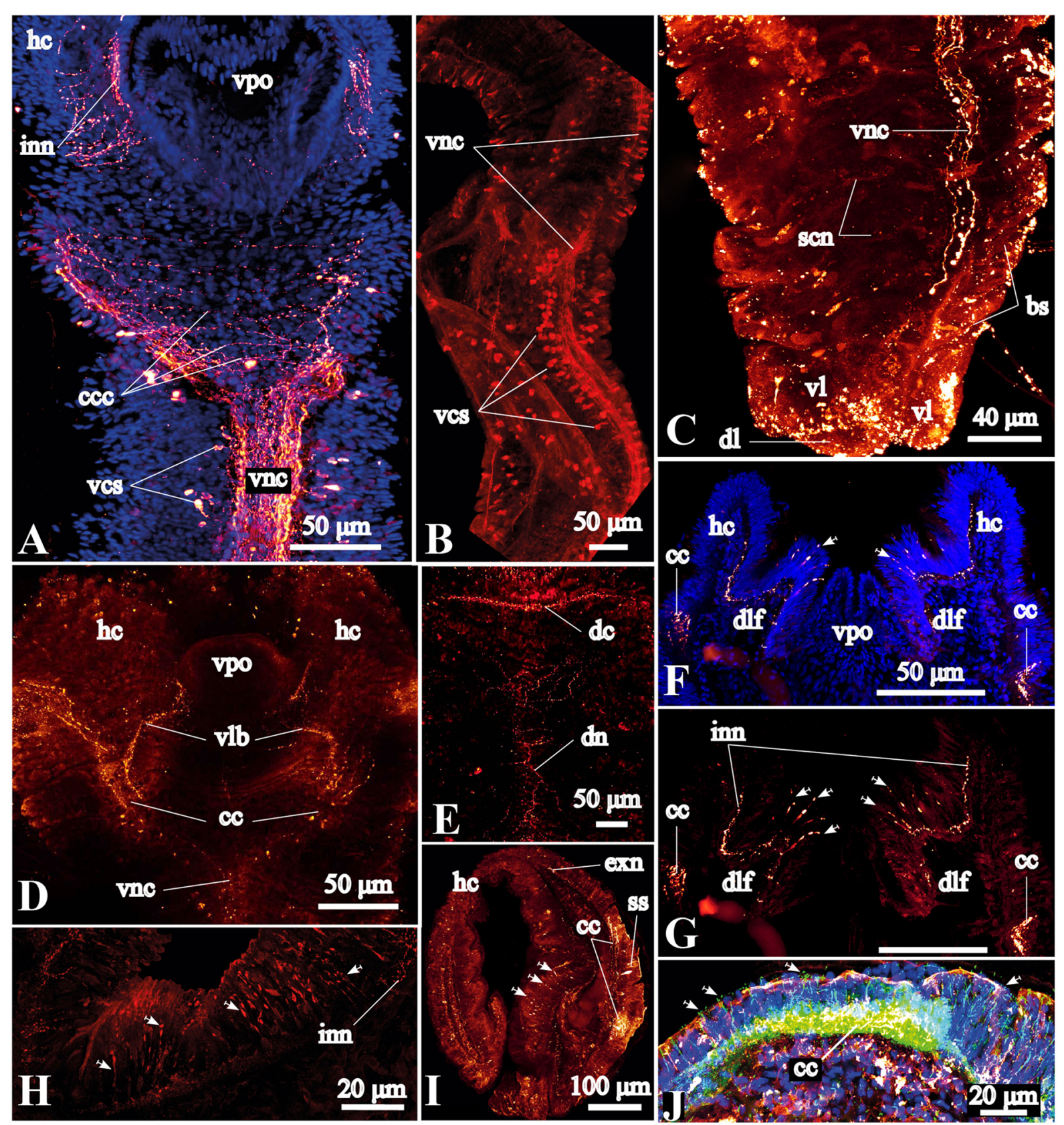

Fig. 5 Serotonin-like immunoreactive (-lir) central nervous system of Galathowenia oculata. Labeling with anti-serotonin (red), anti-acetylated a-tubulin (green) and nuclear labeling with DAPI. Maximum projections $(\mathbf{a}, \mathbf{b}, \mathbf{f}-\mathbf{j})$ and optical sections $(\mathbf{c}-\mathbf{e})$ are shown. Whole-mount stained specimens (b-e), sectioned specimens with 100-200 $\mu \mathrm{m}$ thickness $(\mathbf{a}, \mathbf{f}-\mathbf{j})$. a The serotonin-lir ventral nerve cord and circumesophageal connectives: frontal section, ventral view, anterior end is to the top. $\mathbf{b}$ The medullary organized ventral nerve cord, trunk region, ventrolateral view, anterior is to the top. $\mathbf{c}$ Serotonin-lir neurites of the ventral nerve cord in the posterior-most biramous segments, ventrolateral view, anterior is to the top. $\mathbf{d}$, e Serotonin-lir elements of the head collar: ventral and dorsal views, respectively, anterior is to the top. $\mathbf{f}-\mathbf{h}$ Serotonin-lir elements of the dorsolateral folds (arrows) and the inner wall of the head collar: frontal sections, ventral view, anterior is to the top. i Serotonin-lir elements (arrows) of the outer wall of the head collar: transverse section, ventral is to the bottom. $\mathbf{j}$ Sensory cells (arrows) in epidermis of the outer wall of the head collar: transverse section. bs - short biramous segments, cc - circumesophageal connectives, $c c c$ - transverse neurites interconnecting circumesophageal connectives, $c n$ - serially arranged circular neurite bundles, $d c$ - dorsal commissure, $d l$ - dorsal pygidial lobe, $d l f$ - dorso-lateral folds, $d n$ - main dorsal neurite bundle, exn - epidermal neurite plexus on outer side of head collar, hc - head collar, inn - neurite plexus within the inner side of the head collar epidermis, Iln - main longitudinal neurite bundles of left body side, $n c$ - notopodial capillaries, $n u$ - neuropodial uncini, $r / n$ - main longitudinal neurite bundles of right body side, scn - serotonin-lir serially arranged circular neurite bundles, ss - serotonin-lir somata, vcs - serotonin-lir somata associated with the ventral nerve cord, $v l$ - ventral pygidial lobes, vnc - ventral nerve cord 


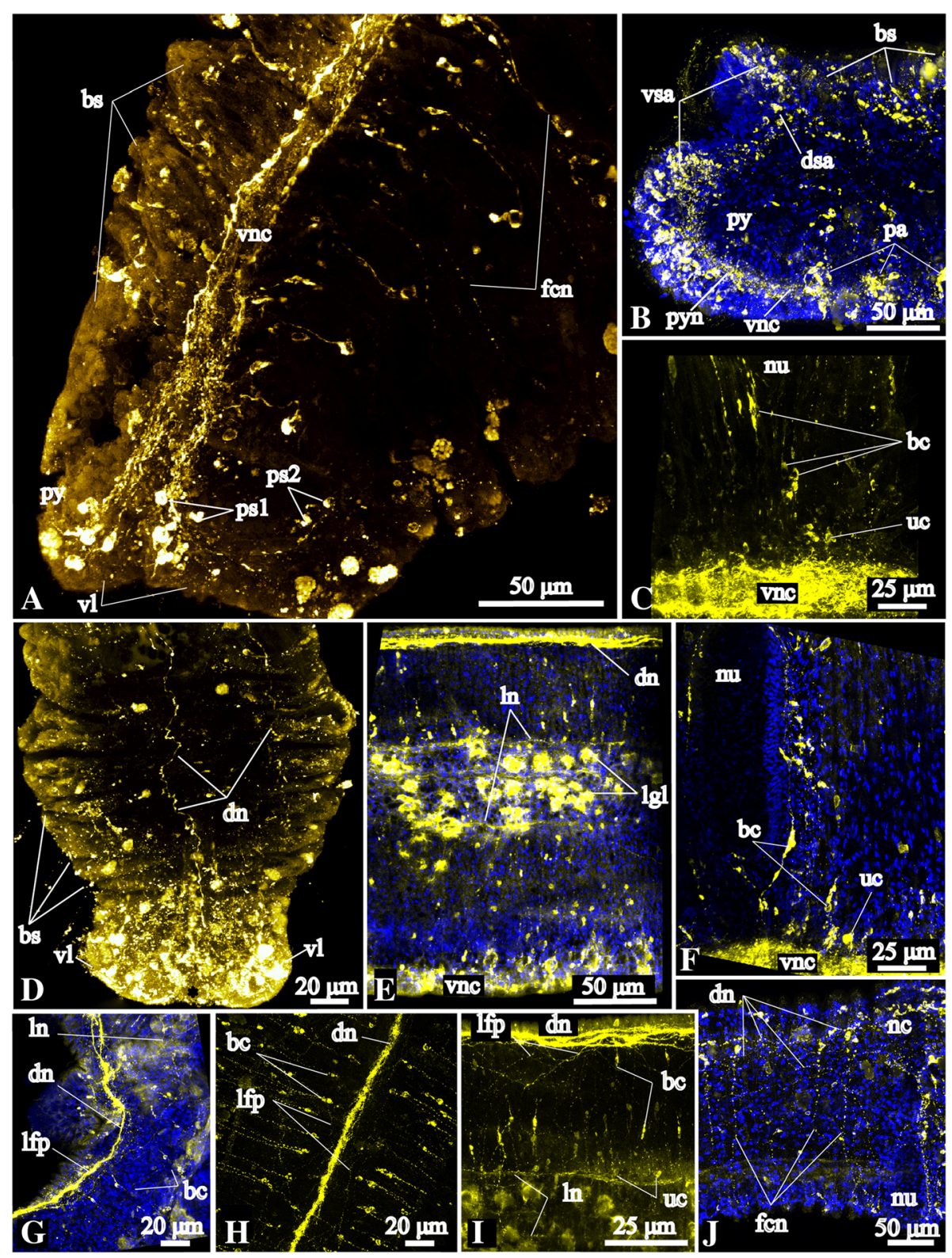

Fig. 6 FMRFamide-like immunoreactive (-lir) nervous system in the trunk and pygidium of Galathowenia oculata. Anti-FMRFamide-lir (yellow), nuclei labeling with DAPI (blue), maximum projections, whole-mount specimens. a Ventral nervous system of the posterior-most segments and pygidium, ventrolateral view, anterior is to the top. Note the immunocytochemically (ICC) positive somata in the ventral and ventrolateral sides of the pygidium. b Pygidial ICC-positive somata accumulations, dorsolateral view of posterior-most chaetigers, anterior to the right. c Distribution of the ICC-positive somata associated with the ventral nerve cord, median portion of body, lateral view, anterior to the left. $\mathbf{d}$ Dorsal neurite bundles of the posterior-most segments, dorsal view, anterior to the top. e Ventral nerve cord and main peripheral longitudinal neurite bundles, left lateral view of anterior portion of body, anterior to the left. $\mathbf{f I C C}$-positive somata associated with the ventral nerve cord, median portion of body, lateral view, anterior to the left. $\mathbf{g}$ Loose condition of the main dorsal neurite bundle in anterior segments, dorsolateral view, anterior to the bottom. h Main dorsal neurite bundle, serially arranged circular neurite bundles with associated bipolar cells and longitudinal neurites of the neurite plexus, dorsal view, anterior to the bottom. i Lateral view of main dorsal and lateral neurite bundles in the anterior body region, anterior to the left. Note the bipolar cells associated with the serially arranged circular neurite bundles. $\mathbf{j}$ Circular fibers of posterior-most segments, lateral view, anterior to the left. bc - bipolar cells, bs - short biramous segments, $d n$ - main dorsal neurite bundle, $d s a$ - ICC-positive somata accumulation in dorsal pygidial lobe, $f C n$ - FMRF-amide-lir serially arranged circular neurite bundles, $n c$ - notopodia capillaries, nu - neuropodial uncini, lgl - autofluorescing glands of lateral band, Ifp - plexus of longitudinal neurites along main dorsal neurite bundle, In - main lateral longitudinal neurite bundles, pa - ICC-positive somata accumulations in segments, ps 1-2 - ICC-positive somata of ventral and ventrolateral sides of pygidium, py - pygidium, pyn - pygidial neurite bundles interconnecting the ventral and dorsal neurite bundles, $u c$ - unipolar cells, $v l$ - ventral pygidial lobes, vnc - ventral nerve cord, vsa - ICC-positive somata accumulations in ventral pygidial lobes 


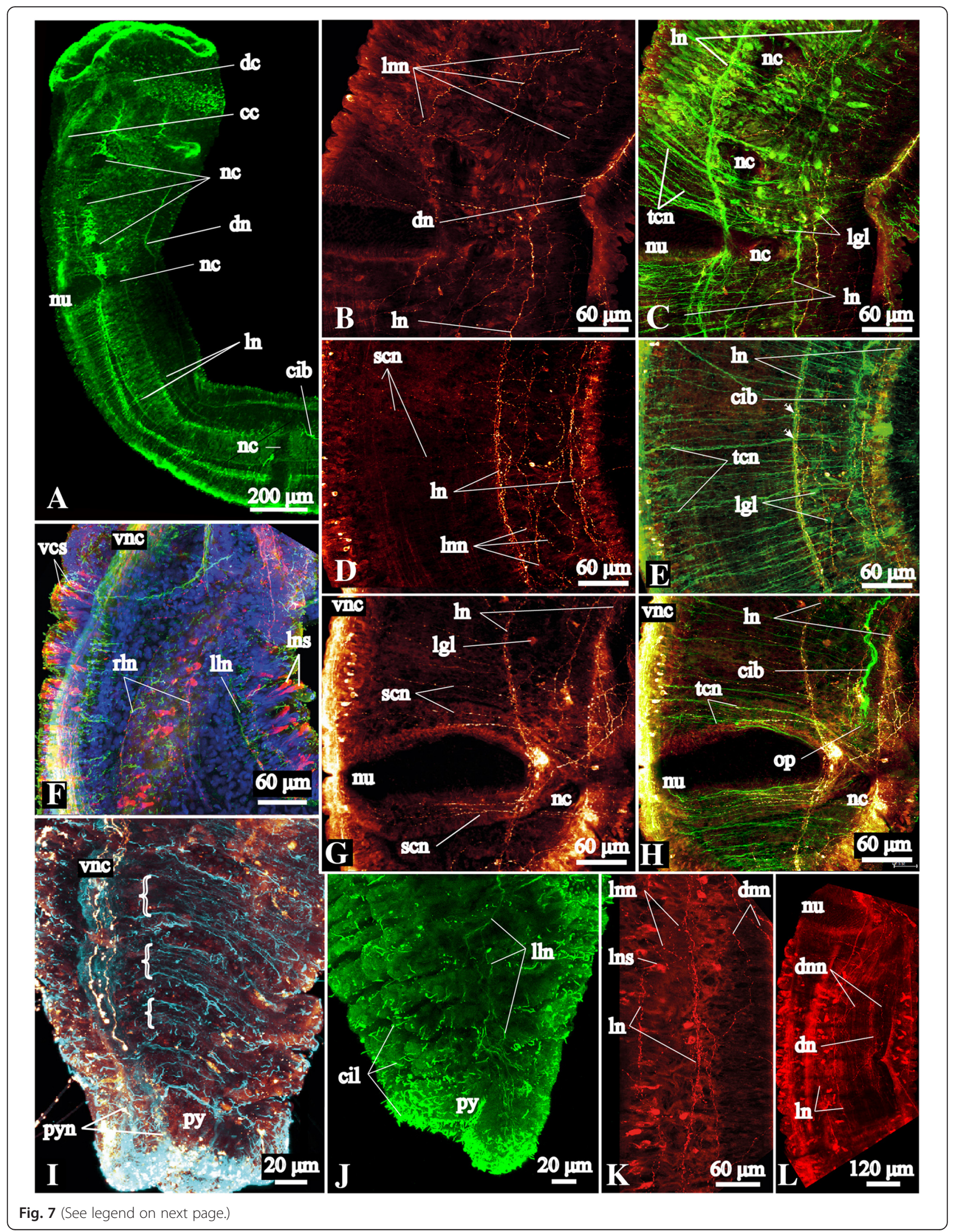


(See figure on previous page.)

Fig. 7 Peripheral nervous system in the trunk of Galathowenia oculata. Anti-acetylated a-tubulin (green, cyan) and anti-serotonin (red) immunoreactivity (lir) nuclei labeling with DAPI (blue), maximum projections, whole-mount specimens. Ventral to the left, anterior to the top. a Main tubulin-lir longitudinal neurite bundles up to the $5^{\text {th }}$ chaetiger, dorsolateral view. $\mathbf{b}$ Serotonin-lir lateral neurite plexus in the $2^{\text {nd }}, 3^{\text {rd }}$ and $4^{\text {th }}$ chaetigers, lateral view. c The same fragment as in B. Main tubulin-lir lateral longitudinal neurite bundles and numerous serially arranged circular neurite bundles. $\mathbf{d}$, e Serotonin-lir and tubulin-lir circular neurite bundles and plexuses between the main longitudinal neurite bundles, the $5^{\text {th }}$ chaetiger, lateral view. Arrows point to ramifying of neurite bundles. $\mathbf{f}$ Serotonin-lir somata of the ventral nerve cord and main longitudinal neurite bundles, the $6^{\text {th }}$ chaetiger, lateral view. $\mathbf{g}, \mathbf{h}$ Serotonin-lir and tubulin-lir circular neurite bundles in the region of the parapodia, posterior portion of the $5^{\text {th }}$ chaetiger, lateral view. i Serotonin-lir and tubulin-lir circular neurite bundles in the posterior-most segments (brackets mark tubulin-lir neurite bundles in each segment), ventrolateral view. $\mathbf{j}$ Tubulin-lir longitudinal neurite bundles in the posterior-most segments, lateral view. $\mathbf{k}$ Serotonin-lir somata associated with the neurite plexus and the main lateral longitudinal neurite bundles, lateral view. I Main serotonin-lir dorsal neurite bundle associated with the dorsal neurite plexus, dorsolateral view. cc - circumesophageal connectives, cib - ciliary bands, cil - cilia, $d c$ - dorsal commissure, $d n$ - main dorsal neurite bundle, $d n n$ - dorsal neurite plexus, $|g|$ - autofluorescent glands of lateral band, IIn - left main lateral neurite bundle, In - main lateral neurite bundle, Inn - lateral neurite plexus, Ins - immunopositive somata associated with the main lateral neurite bundles, $n c$ - notopodia capillaries, $n u$ - neuropodial uncini, op - nephridiopore, py - pygidium, pyn - pygidial neurite bundles interconnecting the ventral and dorsal neurite bundles, $r / n$ - right main lateral neurite bundle, scn - serotonin-lir serially arranged circular neurite bundles, tcn - tubulin-lir serially arranged circular neurite bundles, vcs - serotonin-lir somata associated with ventral nerve cord, vnc - ventral nerve cord. Legend for cover image: Medullary brain commissure of Galathowenia oculata (Oweniidae; Annelida) showing cell nuclei by DAPI staining (blue) and FMRFamide-like immunoreactivity (yellow)

organized evenly. Anti-acetylated $\alpha$-tubulin staining revealed an extensive plexus of neurites that arise from the dorsal commissure anteriorly and run toward the external sides of the head collar (Fig. 3b). This tubulin-like immunoreactive (-lir) plexus comprises FMRFamide-lir and serotonin-lir neurites (see below and Figs. 4d, 5i). Laterally, the dorsal commissure projects into the circumesophageal connectives linked to each other via transverse neurites (Fig. 3c). The circumesophageal connectives loop and project to the ventral side where their roots unite with the ventral nerve cord (Fig. 3c). The middlemost part of the circumesophageal connectives is widest (75 $\mu \mathrm{m}$ in transverse section), from which a pair of broad ventrolateral neurite bundles splits off and projects toward the ventrolateral margin of the head collar (Fig. 3b, c). These bundles also include FMRFamide- and 5HT-lir neurites (see below and Figs. 4d, 5d). The ventrolateral neurite bundles give off neurite bundles that disperse in the epidermis of the internal sides of the head collar as well as the dorsolateral folds (Figs. 2b, 3b, 5d, f, g, h). The dorsal commissure and circumesophageal connectives give off numerous neurites that form a plexus in the epidermis of the outer side of the head collar (Figs. 3b, c, 4c, d). In the head collar epidermis there are numerous primary sensory cells with basal processes that form a plexus and connect to the dorsal commissure, connectives and ventrolateral bundles (Fig. 5j).

FMRFamide-lir neurites within the dorsal commissure and the circumesophageal connectives measure $20 \mu \mathrm{m}$ in thickness and their distribution within the commissure is not even (Fig. 4a, b). The FMRFamide-lir somata are numerous in the head region and do not form accumulations; they lie along the dorsal commissure (cs), are scattered in the epidermis of the head region $(h s)$, and around the eyes (es) (Figs. 2c, 4a-f). The ICC-positive somata that are localized in the outer wall of the head collar anteriorly to the dorsal commissure are bipolar cells with a diameter between 2 to $6 \mu \mathrm{m}$, while around the eyes the ICC-positive somata are large, elongated cells $(6-7 \times 2 \mu \mathrm{m})$ that are arranged in circular accumulations (Fig. 4d). The FMRFamide-lir dorsal commissure interconnects with the right and left circumesophageal connectives. The circumesophageal connectives give rise to a pair of neurite bundles that run to the ventral and ventrolateral sides of the head collar (Fig. 4d). The pair of FMRFamide-lir circumesophageal connectives interconnected by tiny transverse commissures projects into the ventral nerve cord (Fig. 4c).

Few anti-5-HT neurites are present in the dorsal commissure and the circumesophageal connectives (Figs. 2b, $5 \mathrm{a}, \mathrm{d}, \mathrm{e}, \mathrm{i})$. Fine commissural neurite bundles are present between the circumesophageal connectives; they are oriented transversely and ramify between each other (Fig. 5a). The serotonin-lir ventrolateral neurite bundles arise from each circumesophageal connective (Fig. 5d). Neurites from these ventrolateral bundles project toward the inner wall of the head collar (Fig. 5d). Numerous serotonin-lir cells are distributed in the epidermis of the collar and in the dorsolateral folds (Fig. 5f-i). These cells are connected to the neurite plexuses within the inner and outer part of the head collar body wall (Figs. 5a, g-i). The neurite plexus on the outer walls of the head collar has mostly connections to the circumesophageal connectives (Fig. 5i), while the neurite plexus on the inner wall of the head collar mostly connect to the ventrolateral neurite bundles (Fig. 5d, g, h). Relatively large serotonin-lir somata which are elongated $(10-20 \times 5 \mu \mathrm{m})$ are located along the circumesophageal connectives (Fig. 3i). Neither serotoninlir nor FMRFamide-lir somata were found in the ventral pharyngeal organ. 


\section{Ventral nerve cord}

Anti-acetylated $\alpha$-tubulin, anti-5HT and anti-FMRFamide staining reveals the prominent single ventral nerve cord (Figs. 2a-c, 3a, f, 4c, 5a, b, 6a). All stainings showed that the ventral nerve cord extends from roots of the circumesophageal connectives, i.e., from the level of the first chaetiger until the posterior-most segment. A few neurites of the ventral nerve cord continue into the pygidium where they split into two bundles, projecting into the paired ventral pygidial lobes. These bundles run towards the dorsal side and connect to the main dorsal neurite bundle (see below). Neurites and ICC-positive somata of the ventral nerve cord labeled with various antibodies are organized in different ways.

Acetylated $\alpha$-tubulin-lir shows that the transverse profile of the ventral nerve cord has two lobes, i.e., it constitutes a paired structure (figure-of-eight) (Fig. $3 g, \mathrm{~h}$ ). Besides, there are two collateral fine neurite bundles that run in parallel to the ventral nerve (Fig. 3c, e). FMRFamide-lir and serotonin-lir neurites of the ventral nerve cord are not paired and are not present in the collateral bundles (compare Figs. $3 \mathrm{c}$ with $4 \mathrm{c}$ and $5 \mathrm{a}$ ).

The FMRFamide-lir elements of the ventral nerve cord are distributed along the entire length of the worm including the posterior-most segment (Figs. 2c, 6a-c, e, f). Two neurite bundles of the ventral nerve cord extend into the pygidium (Fig. 6a, b). Somata labeled with antibodies against FMRFamide are located pairwise along the left and right sides of the ventral nerve cord (Fig. 6a, c, f). Most of the ICC-positive somata are small $(4-5 \mu \mathrm{m})$ and have a drop-like shape; other somata are large, around 9-11 $\mu \mathrm{m}$ in diameter. In the posterior (short) segments ICC-positive somata form accumulations in the anterior parts of each segment (Fig. 6b).

Serotonin-lir neurites in the ventral nerve cord are numerous in the anterior segments and their number decreases in the posterior short segments (Figs. 2b, 5b, c). Few neurite bundles reach the posterior-most segment. Serotonin-lir somata are scattered continuously bilaterally arranged by pairs along the ventral nerve cord (Figs. 5b, 7f). There are around 6-8 pairs of ICCpositive somata in the short uniramous segments. In the biramous segments, there are 50-100 pairs of somata within the long segments and 6-8 pairs per short segment. ICC-positive somata are large and elongated (16-20 $\mu \mathrm{m}$ in length). There are no ganglion-like structures along the ventral nerve cord, but there are gaps between accumulations of the serotonin-lir somata (for example, at the levels of the neuropodia; Fig. $7 \mathrm{~g}$ ).

\section{Main peripheral longitudinal neurite bundles}

In Galathowenia oculata there are five main peripheral longitudinal neurite bundles: an unpaired dorsal one and two pairs of lateral ones running along the lateral glandular bands and notopodial chaetae (Figs. 2a-c).

Five tubulin-lir main peripheral longitudinal neurite bundles are present in the first uniramous segment and give off short branches into the peristomium (Figs. 2a, 7a, $c, e, h, j)$. The lengths of the main longitudinal neurite bundles differ (Fig. 2a): the main dorsal longitudinal neurite bundle ( $4-5 \mu \mathrm{m}$ in thickness) extends into the pygidium. Two pairs of the main lateral tubulin-lir neurite bundles run along both sides of the notopodial chaetae (Fig. 7c); in the long biramous segments they run along both sides of the glandular bands and the ciliary bands (Figs. 7a, e, h). The ventro-lateral neurite bundles are more prominent $(8 \mu \mathrm{m}$ in diameter) than the dorso-lateral pair ( $4 \mu \mathrm{m}$ in diameter). Few lateral tubulin-lir neurite bundles are visible in the posterior-most segments (Fig. 2a, 7j).

FMRFamide-lir neurite bundles were revealed within each of the main longitudinal tubulin-lir neurite bundles, the unpaired dorsal and the two pairs of lateral bundles (Figs. 2c, 4a, b, 6e). The main dorsal FMRFamide-lir neurite bundle runs from the first chaetiger into the pygidium (Figs. 4a, b, 6b, d). The diameter of the FMRFamide-lir dorsal neurite bundle varies between 1 and $5 \mu \mathrm{m}$. In the uniramous and anterior biramous segments the FMRFamide-lir dorsal neurite bundle is wider, loose, and often branched (Fig. 6g, i). There are numerous additional longitudinal neurites on both sides of the dorsal neurite bundle. These neurite bundles ramify, join the main lateral neurite bundles and have connections with the circular neurite bundles, thereby forming an intraepidermal neurite plexus (Fig. $6 \mathrm{~g}-\mathrm{i}$ ). The middlemost part of the main dorsal neurite bundle is thinner and denser (Fig. 6h) than in the anterior part of the worm; posteriorly it is represented by individual widely spaced neurite bundles (Fig. 6j). ICC-positive somata are present along the entire length of the main dorsal neurite bundle and in the dorsal peristomium (Figs. 4b, e, $6 \mathrm{~g}-\mathrm{i}$ ). The main dorsal neurite bundle in particular includes the neurites of bipolar FMRFamide-lir cells (Fig. 6h). The main dorsal neurite bundles as well as numerous tiny neurites from the dorsal part of the intraepidermal plexus in the peristomium have connections to the dorsal brain commissure (Figs. 2c, 4b, e). FMRFamide-lir main lateral longitudinal neurite bundles were found along the glandular band (Figs. 1e, 6e, i). The main lateral FMRFamide-lir neurite bundles are equal in diameter (compare with the serotonin-lir ones), around 1-2 $\mu \mathrm{m}$, and do not split. FMRFamide-lir unipolar and bipolar cells are associated with the main lateral neurite bundles (Fig. 5i).

Serotonin-lir was also revealed in the five main peripheral longitudinal neurite bundles (Figs. 2b, 7d, f, k). The unpaired main dorsal neurite bundle $(3 \mu \mathrm{m})$ gives off some neurites into the head (mostly in the peristomium) which ramify there into the plexus (Fig. 5e); posteriorly, 
these neurites form the main dorsal neurite bundle that extends along the length of the body (Figs. 2b, 7b, 1). Somata labeled with antibodies against 5HT were not found in the main dorsal neurite bundle. There are two pairs of main lateral longitudinal neurite bundles extending from the fourth chaetiger (Fig. 7b) and terminating at different levels. The dorsolateral pair extends until the end of the eighth chaetiger, while the ventrolateral pair extends to the middle part of the ninth chaetiger. At the anterior and posterior ends of the lateral neurite bundles there are plexuses of numerous neurites projecting in different directions (Figs. 7b). Serotonin-lir unipolar cells spread along the main lateral longitudinal neurite bundles are large, $12 \mu \mathrm{m}$ in length, and conical (they have wide apical parts and narrow basal parts that give off neurites) (Fig. 7f, k).

\section{Circular neurite bundles and plexuses}

Anti- $\alpha$-tubulin immunofluorescence shows regularly arranged circular neurite bundles extending from the ventral nerve cord to the main longitudinal neurite bundles (Figs. 2a, 7c, e, h). The number of the bundles increases with the length of the segment. Accordingly, there are about six to seven neurite bundles per short uniramous segment, while there are up to 60 neurite bundles per long biramous segment. Thick serially arranged bundles are semicircular; they extend from the ventral nerve cord to the main lateral longitudinal neurite bundles. As they reach the main ventrolateral longitudinal neurite bundles they split into two to three finer neurite bundles that extend to the main dorsolateral longitudinal neurite bundles (Fig. 7e). These circular neurite bundles underlie the bands of cilia and glands (Figs. 1e, 7c, e). A few fine circular neurite bundles extend to the main dorsal neurite bundle. In posterior short segments, circular tubulin-lir neurite bundles exhibit the tendency to concentrate (Figs. 2a, 7i). Surrounding the noto- and neuropodia there are tiny circular tubulin-lir neurite bundles (Fig. 7h).

FMRFamide-lir circular neurite bundles are abundant and associated with regularly spread bipolar cells $(6 \mu \mathrm{m}$; Figs. 2c, 6a, c, f-j). Most FMRFamide-lir bipolar cells lie posterior to the parapodia (Figs. 6c, f). From the head to the pygidium the number of the neurite bundles per chaetiger decreases (Figs. 2c, 6a, h).

Serotonin-lir circular neurite bundles are arranged irregularly (Fig. 7d, g). They do not form bundles, except around the parapodia (Fig. $7 \mathrm{~g}$ ). Serotonin-lir somata are found associated with the ventral nerve cord and with the main lateral longitudinal neurite bundles, but not with the dorsal one (Fig. 7f, k, l). Serotonin-lir neurites of the lateral (Fig. 7k) and dorsal (Fig. 7l) longitudinal neurite plexuses show longitudinal, transverse and oblique orientations.

\section{Pygidial neural elements}

The ventral nerve cord revealed by tubulin-lir extends to the pygidium and splits into two bundles, which then turn dorsally and join the main dorsal neurite bundle. FMRFamide-lir neurites of the ventral nerve cord project into the pygidium and divide into two branches that run into the ventral pygidial lobes, then around the anus and to the dorsal side, where they connect to the main dorsal longitudinal neurite bundle (Figs. 1c, 6a, b). The pygidium exhibits a vast number of FMRFamide-lir somata. Some of them are associated with the ventral nerve cord and lie either close to or at the lateral sides of the pygidium (Fig. 6a). Moreover, within the pygidium there are three accumulations of large somata $(6-8 \mu \mathrm{m})$ lying close to each other in the epidermis and adjacent to the pygidial neurite bundles (vsa, Fig. 6b). Around 60 somata are accumulated in each ventral pygidial lobe. The third accumulation contains 10-20 somata in the dorsal lobe (dsa, Fig. 6b) of the pygidium, which is heavily ciliated (Fig. 1g). We did not find any serotonin-lir elements in the pygidial lobes.

\section{Discussion}

Central nervous system gross architecture of

\section{Galathowenia oculata}

Our study is the first investigation of the nervous system in a representative of Oweniidae using immunocytochemical methods in combination with confocal laser-scanning microscopy, a method proven to be effective for the study of the nervous systems in numerous invertebrate taxa including annelids [40-42]. An intraepidermal position of the nervous system, as in G. oculata, has been regarded as the plesiomorphic state for Bilateria [41, 43-45]. Such a basiepithelial position is found in many annelid groups [41, 43, 46]. An intraepidermal CNS is also characteristic for the oweniids and their putative sister group, the magelonids $[3,12,35,47,48]$ and we therefore suggest that it was also present in the last common ancestor of Oweniidae.

\section{Medullary brain commissure}

In general, the supraesophageal ganglion of annelids comprises a compact central mass of neuropil surrounded by a cell cortex [49]. Our study did not reveal a ganglionic organization around the dosal commissure in Galathowenia oculata. Serotonin-lir and FMRFamide-lir somata do not form a compact cell cortex and tubulinlir neurite bundles do not form a swelling within the dorsal commissure (Figs. 2a-c, 4a, b, 5d, i). Few pairs of serotonin-lir somata were found on the lateral sides of the dorsal commissure. FMRFamide-lir unipolar somata are numerous and uniformly distributed along the loop of the dorsal commissure and the circumesophageal connectives. Nerve cords or neurite bundles that are surrounded by a cellular cortex are commonly termed 
medullary nerve cords/bundles [49]. This conforms to the situation found in the oweniid dorsal brain commissure analysed herein and we therefore use the term "medullary brain commissure" for the respective structure. A similar organization of the neurite loop without a ganglion-like thickening is known from Echiura, where along the neurite loop of Bonellia viridis and Urechis caupo numerous FMRFamide-lir somata and several pairs of serotonin-lir somata were found [40, 50-52]. So far, there is not enough data for explanation of the absence of a distinct supraesophageal ganglion and presence of the only thick commissure in both taxa, Oweniidae and Echiura. For example, it might be due to a similar way of deposit feeding, or overall sedentary lifestyle, or developmental processes etc. Also, this data has to be confirmed by transmission electron microscopy or histology-based studies, since labeling of FMRFamides and serotonin only visualizes those parts of the nervous system that contain the respective neuroactive substances [46].

\section{Number of brain commissures}

The presence of four transverse commissures has been considered as the most conservative feature of the adult brain in Annelida [41, 53]. Staining against acetylated $\alpha$ tubulin has shown that there is only one thick brain commissure in Galathowenia oculata (Figs. 2a, 3b). Bubko and Minichev [34] showed that Owenia fusiformis has two commissures; a main brain commissure and an additional minute supraesophageal commissure that supposedly emerges from the nuchal organ. No nuchal organ was found in any of our specimens of G. oculata. Capa et al. [3] also stated the absence of nuchal organs in this taxon in their taxonomic revision of Oweniidae. Accordingly, the additional commissure found in Owenia fusiformis may emanate from the tentacles. Species from the genus Owenia have a pronounced tentacle crown serving for gas exchange and collection of food particles as well as particles for tube building. In species of the genus Galathowenia there are no tentacles [3], and collection of particles is performed with the ventral pharyngeal organ (which is absent in Owenia) and the dorsolateral folds of the collar (see below and Fig. 1c, d).

A single supraesophageal commissure can be found in various tubicolous and burrowing annelids including Pectinariidae, Terebellidae, Ampharetidae, Chaetopteridae [41], Arenicolidae [54], Maldanidae [55] and Echiura $[40,50-52]$. All of them share a combination of behavioral features as burrowing sediment dwellers, resting inside their tubes/burrows and feeding on sediment deposits. Probably due to these habits there is no demand to form numerous diverse head appendages with sensory organs requiring well-developed transverse commissures and this might be the reason why there is only a single dorsal commissure in G. oculata.
Nonetheless, in all annelids that have ever been regarded as a sister clade to Oweniidae (e.g., "archiannelids", Apistobranchiidae, Sabellida, Siboglinidae, Terebellida, Magelonidae) there is no similar organization of a brain commissure as a single neurite loop. The group of errant depositfeeders previously known as "archiannelids" exhibits a well-developed ganglion and a prominent brain neuropil (e.g., Protodrilidae, Saccocirridae, Dinophilidae and Nerillidae) or have two roots of circumesophageal connectives (e.g., Polygordiidae) [56-61]. Sedentary filter-feeding annelids such as Sabellidae, Sabellariidae and Serpulidae have four supraesophageal commissures [41, 62]. Evidently, the complex brain structure of sedentary annelids can be explained by the presence of the various appendages involved in filtration. In Siboglinidae there is a complex brain with several commissures [63-67]. In vestimentiferan siboglinids there is a prominent brain including a subesophageal and a supraesophageal ganglion with two transverse commissures. A brain with such complexity corresponds to their large tentacle apparatus $[64,66,68]$. In tiny frenulate siboglinids there is an additional tentacular neurite commissure $[63,65]$, and even in dwarf males of Osedax there are two commissures [67]. Magelonidae, Orbiniidae, Flabelligeridae, Apistobranchidae, Poecilochaetidae, Trochochaetidae, Scalibregmatidae and Paraonidae all exhibit four brain commissures that likely correspond to a mode of life as errant sediment burrowing annelids that are deposit or suspension feeders $[41,62,69,70]$. Thus, the number of brain commissures in adult annelids is largely a reflection of their mode of life that can hardly be used for phylogenetic inferences.

\section{Dorsolateral folds and head collar innervation}

For the first time the innervation of the dorsolateral folds and the anterior margin of the head collar of Galathowenia oculata are described (Figs. 2b, g, h, j, 1-o, 6a-c). The head collar contains numerous serotonin-lir and FMRFamide-lir somata, while the dorsolateral folds contain somata labeled with antibodies against serotonin. Both the head collar and dorsolateral folds are covered by cilia and are involved in sediment particle sorting. The newly revealed somata in these organs might suggest that they are involved in sensory perception, which is known from ciliated sensory cells in tentacles in a number of annelids [56, 71-73]. The ventrolateral neurite bundles include neurites in the head collar and the dorsolateral folds (Figs. 2, 3b, 4d, 5a, d, f-h). To date, similar neurite bundles branching off from circumesophageal connectives have not been shown in other annelids.

\section{Medullary ventral nerve cord}

According to our immunocytochemical stainings, the ventral nerve cord of Galathowenia oculata is medullary organized; FMRFamide-lir and serotonin-lir somata are 
scattered evenly along the anterior part of the ventral nerve cord (Figs. 2b, c, 5b, 6e). There are neither distinct ganglia nor swellings in the nerve cord of G. oculata. Although the latter were found in Owenia fusiformis in the fourth and ninth segments, this was explained by the presence of complex dissepiments serving as sphincters [14, 34].

A medullary ventral nerve cord is common in several annelids belonging to different phylogenetic lineages: Polygordius, Chaetogordius, Saccocirrus, Protodrilus, Oweniidae, Magelona, Siboglinidae, Echiura, some species of Opheliidae and Maldanidae [40, 43, 47, 51, 68, 74]. A ventral nerve cord with ill-defined ganglia is also known for some oligochaetes such as Naididae or Enchytraeidae or some Lumbricidae $[43,45,75-79]$. Most of the taxa mentioned above are regarded as either specialized interstitial meiofaunal animals [80-82] or sedentary sediment feeders [3, 40, 55, 74].

In long segments of G. oculata FMRFamide-lir somata are distributed evenly, whereas in short posterior segments somata tend to accumulate (compare Fig. $6 \mathrm{~b}$ and 6e). A similar situation is found in Siboglinidae. For instance, in frenulate siboglinids ganglia of the ventral nerve cord are present in short segments of the opisthosoma, whereas in the very long segments of the trunk and the forepart the ventral nerve cord is medullary [74]. Likewise, Protodrilidae, Polygordiidae and Maldanidae have elongated segments and a medullary condition of the ventral nerve cord [43, 46, 55]. Accordingly, the medullary organization of the ventral nerve cord described herein for G. oculata might be due to the elongation of short segments that might have occurred in the last common oweniid ancestor. Very likely, the elongation of segments emerged in different lineages of annelids due to their particular life history or ecology (e.g., sessile or interstitial). Whether or not a medullary nerve cord is only found in representatives that have long segments remains to be shown by future investigations.

\section{Unpaired ventral nerve cord}

During development of the oweniid mitraria larva two separate ventral neurite bundles fuse to a single one [5]. Adult Galathowenia oculata show a profile of the ventral nerve cord that appears figure-eight-shaped along its entire length (Figs. 3g, h). We hypothesize the fusion of both cords in G. oculata. Transformation of a widely separated pair of ventral neurite bundles into a single cord during larval development is shown for instance in other Oweniidae, Sipuncula, and Echiura [5, 40, 42, 52]. Therefore, it appears plausible that the dineuronal organization of the ventral nerve cord is an ancestral feature for Oweniidae as it has been already suggested for all annelids [43], although there are other views [53].

There are two widely separated neurite bundles, the circumesophageal connectives, in G. oculata (Fig. 2) and other Oweniidae [3]. These are also visible in the second anterior segment of siboglinids [64, 66, 68, 83, 84], which were considered as sister group to Oweniidae [18]. Also, there are paired ventral neurite bundles in Mageloniidae and Chaetopteridae [47, 48]. In vestimentiferan siboglinids, two neurite bundles interconnect the subesophageal ganglia and the ventral nerve cord [68, 84]. On the other hand, in Magelonidae, Oweniidae and Chaetopteridae, these neurite bundles are the circumesophageal connectives and most likely homologous to each other [34, 47, 48]: they unite at the level of the first setiger in oweniids (Fig. 2) [3], the ninth setiger in Magelona sp. [47] and the twelfth setiger in Chaetopterus variopedatus [48]. This is one of the morphological features shared between oweniids, magelonids and chaetopterids, but not with the siboglinids.

\section{Peripheral nervous system}

Five main peripheral longitudinal neurite bundles are known from Owenia fusiformis [34] and are also reported herein for Galathowenia oculata (Fig. 2). The most prominent main neurite bundle is the dorsal one. For the first time the dorsal neurite bundle is found to have a connection to the CNS in oweniids. It extends from the dorsal brain commissure and connects through two pygidial neurite bundles with the ventral nerve cord (Figs. 2a, c, 3f, 6a, b, 7i). In Polygordius appendiculatus there is likewise a connection of the main dorsal neurite bundle to the brain [46]. The number and arrangement of the main peripheral longitudinal neurite bundles varies considerably among annelid representatives $[41,46]$ and might reflect their mode of life rather than their phylogeny.

In the long biramous segments of G. oculata there are numerous circular neurite bundles serially arranged along the body wall of each segment, whereas the short biramous segments exhibit a smaller number of rather thick circular neurite bundles that are associated with the noto- and neuropodia (Figs. 2, 7a). A similar arrangement of circular neurite bundles is also found in vestimentiferan siboglinids. In the large segments (vestimentum and trunk) there are numerous circular neurite bundles, while only one pair of circular neurite bundles is present in each of the tiny opisthosomal segments [85]. Thus, in G. oculata, and likely all oweniids, the number and arrangement of circular neurite bundles is defined by the length of the segments.

In general, the number of circular serially arranged neurite bundles branching off from the ventral nerve cord is highly variable in Annelida [41]. The number of circular neurite bundles per segment is probably constrained by the overall morphology that is adapted to its particular ecology. We suppose that it is not beneficial to argue what is the ancestral condition, several pairs [43] or numerous circular neurite bundles per segment $[34,53]$. 


\section{Pygidial innervation}

For the first time three clusters of numerous somata were found in the pygidial lobes in oweniids (Figs. 6a, b). In this study, we could not confirm that these ICC-positive somata accumulations are organized as ganglia [49]. However, ultrastructural studies are needed to confirm if there is a neuropil surrounded by cell bodies (cortex) that commonly defines a ganglion.

In annelids the innervation of the pygidium has only been poorly studied. In species bearing pygidial appendages there have been serotonin-lir and FMRFamide-lir somata reported [86-88], while in the orbiniid Nainereis, that lacks pygidial appendages, mostly FMRFamide-lir somata are present (Victor Starunov, personal communication). In G. oculata the pattern of the pygidial neurites is congruent with annelids that lack pygidial appendages. The presence of the somata accumulations together with the ciliary epidermis of the pygidial lobes (Figs. 1g, 3f) suggests that they might form the sensory centers of the pygidium.

\section{Conclusions}

This is the first study of the oweniid nervous system by means of immunocytochemistry and confocal laser scanning microscopy. The "medullary brain commissure" of Galathowenia oculata (and possibly all oweniids) is a neuroanatomical feature only known from one other annelid taxon, Echiura. Both taxa exhibit a single brain commissure, a burrowing mode of life and lack head appendages. Circumesophageal connectives and the ventral nerve cord of G. oculata are medullary organized and most likely a derived feature within the annelids. The only accumulations of ICC-positive somata are associated with eyes and pygidial lobes and do not form ganglia. The single ventral nerve cord is paired along its entire length. In G. oculata the neuronal elements are distributed differently in the segments of different length. Long segments exhibit numerous serially arranged circular neurite bundles and the medullary ventral cord. In short biramous segments ICC-positive somata and circular neurite bundles are metamerically arranged. Although Oweniidae (together with Magelonidae) appears as a sister clade to the rest of Annelida in contemporary phylogenomic analyses, many features of its nervous system listed above greatly deviate from that found in most annelids as well as from most putative annelid sister groups, suggesting that these are derived rather than plesiomorphic annelid conditions that evolved along the line leading to the Oweniidae.

\section{Methods}

\section{Collection and fixation of Galathowenia oculata}

Adult Galathowenia oculata typically inhabit muddy sediments. The specimens were collected by dredging from about 30-40 m depth in the Kandalaksha Bay near

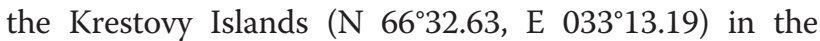
vicinity of the White Sea Biological Station, Lomonosov Moscow State University, Russia, in September 2012 and June-July 2013. Worms were extracted from their tubes, anesthetized in $5.1 \% \mathrm{MgCl}_{2}$ in seawater, and fixed in $4 \%$ paraformaldehyde (PFA) in $0.1 \mathrm{M}$ phosphate-buffered saline (PBS, $\mathrm{pH}$ 7.4) for $4 \mathrm{~h}$ at room temperature (RT) or overnight at $4{ }^{\circ} \mathrm{C}$, rinsed thrice in $0.1 \mathrm{M} \mathrm{PBS}$ and stored in $0.1 \mathrm{M}$ PBS with $0.1 \% \mathrm{NaN}_{3}$ at $4{ }^{\circ} \mathrm{C}$ for further scanning electron microscopy (SEM) and immunocytochemical studies. Specimens for transmission electron microscopy (TEM) were fixed in $3 \%$ glutaraldehyde in $0,1 \mathrm{M}$ PBS with $3 \%$ sucrose and later postfixed in $1 \%$ osmium tetroxide for one hour.

\section{Immunolabelling}

The following staining procedures and antibodies were used: DAPI (Invitrogen, Eugen, OR, USA), monoclonal mouse anti-acetylated $\alpha$-tubulin (Sigma-Aldrich, St. Louis, MO, USA) with Alexa Fluor 488-labeled secondary antibody directed against mouse (Invitrogen); polyclonal rabbit anti-serotonin (Zymed, San Francisco, CA, USA) with either an Alexa Fluor 568-labeled secondary antibody directed against rabbit (Invitrogen) or with an Alexa Fluor 633-labeled secondary antibody directed against rabbit (Invitrogen); polyclonal rabbit anti-FMRFamide (Chemicon, Temecula, CA, USA) with TRITC-labeled secondary antibody against rabbit (Sigma-Aldrich). Various combinations of double and triple stainings were used for the species investigated.

Prior to whole-mount staining of specimens, unspecific binding sites were blocked in PBT (PBS containing $10 \%$ Triton-X-100) and $4 \%$ normal goat serum (Invitrogen) overnight at $4{ }^{\circ} \mathrm{C}$. One or two primary antibodies were applied (mixed 1:1 with double concentrations; diluted 1:500 in PBT with $4 \%$ NGS) and incubated for $48 \mathrm{~h}$ on a shaker at room temperature (RT). Afterwards, the samples were washed several times with PBT and one or two secondary antibodies were applied in a dilution of 1:300 in PBT with $1 \%$ NGS for $12 \mathrm{~h}$ on a shaker at RT. Thereafter, animals were incubated for $1 \mathrm{~h}$ in DAPI in PBS in a 1:40 dilution and rinsed several times in PBS before specimens were mounted in Fluoromount G (Sigma-Aldrich) or glycerol between 2 coverslips to allow scanning of animals from both sides. Negative controls were performed by omitting the primary antibody and rendered no signal. Total number of used specimens in the study was 37 (including 12 specimens as controls).

\section{Immunocytochemical staining of vibratome sections}

Prior to sectioning, pieces of adults of Galathowenia oculata were rinsed in $0.1 \mathrm{M}$ PBS over $20 \mathrm{~min}$ at $4{ }^{\circ} \mathrm{C}$. Samples were embedded in a gelatine-ovalbumine 
solution and stored in $10 \%$ formaldehyde in $0.1 \mathrm{M}$ PBS overnight at $4{ }^{\circ} \mathrm{C}$. Thereafter, samples were rinsed in $0.1 \mathrm{M}$ PBS for 4-5 h, then sectioned in transverse, parasagittal and parafrontal $50-150 \mu \mathrm{m}$ thick sections using a Leica VT1200S vibratome (Leica Microsystems, Wetzlar, Germany). Vibratome sections were stained in the same manner as whole-mounts, but for permeabilization the PBT contained $2 \%$ Triton X-100. Incubation in primary antibodies was reduced to $24 \mathrm{~h}$. Dilution of antibodies was increased to 1:600 for primary antibodies and 1:800 for secondary antibodies. Animals were mounted in Elvanol [89] on glass slides.

\section{Confocal microscopy}

All samples were investigated with a Leica TCS SP5 confocal microscope (CLSM) (Leica Microsystems, Wetzlar, Germany) or a Nikon A1 CLSM (Nikon Corporation, Tokyo, Japan). Leica or Nikon imaging software was used to generate optical sections with a Z-step size of $0.1-1.5 \mu \mathrm{m}$ which were digitally merged to yield maximum and average projection images. Depth-coded Zstack images, obtained with the Leica software provided with the confocal microscope, follows the area of the spectral light, with the uppermost structures appearing blue and the more distant ones red. All images were further processed with Adobe Photoshop CS6 (Adobe Systems, San Jose, CA, USA) to adjust contrast and brightness. Drawings were generated with Adobe Illustrator CC.

\section{Electron microscopy}

For scanning electron microscopy Galathowenia oculata specimens were postfixed in $1 \% \mathrm{OsO}_{4}$ and dehydrated in an ascending ethanol and acetone series, critical point dried and then sputter coated with platinum-palladium. Specimens were examined with a JEOL JSM scanning electron microscope (JEOL Ltd., Tokyo, Japan).

For transmission electron microscopy specimens were dehydrated in an alcohol series using standard protocols and thereafter polymerized for $20-24 \mathrm{~h}$ at $50{ }^{\circ} \mathrm{C}$ and embeded in Epon. The block was trimmed to the object and sectioned into ultrathin $(50-70 \mathrm{~nm})$ sections using a Leica EM UC7 ultramicrotome (Leica Microsystems, Wetzlar, Germany). Ultrathin sections were mounted on slot grids and mesh grids, contrasted with $2 \%$ uranyl acetate- and $4 \%$ lead citrate-solution and examined using a Zeiss Libra 120 electron microscope (Zeiss, Oberkochen, Germany).

\section{Documentation of adult specimens}

Images of adults were taken using a Leica DFC420C (5.0MP) camera mounted on a Leica DM2500 dissecting microscope. Images were processed with Leica Application Suite software.

\section{Competing interests}

The authors declare that they have no competing interests.

\section{Authors' contributions}

NNR-K designed the study, collected animals, carried out studies on the confocal and electron microscopes, analyzed data and drafted the manuscript. AK and AW coordinated the confocal microscopy research. AW contributed to data interpretation, evolutionary discussions and writing of the manuscript. All authors contributed to data analysis and to the writing of the manuscript.

\section{Acknowledgements}

We thank the crew of the RV "Student" and "Strizh" as well as Alexander Tzetlin, Vladimir Chava, Denis Nikishin, Stanislav Kremnyov and Yulia Khramova for their continuous help and supply of specimens of Galathowenia oculata. Tim Wollesen and Thomas Schwaha educated NNR-K in immunocytochemical methods; Natalia M. Biserova and Brett C. Gonzalez are thanked for their discussions that improved the manuscript. The Laboratory of the Electron Microscopy in the Moscow State University is thanked for the SEM analysis. NNR-K was supported in part by several grants. The material was collected with support from the Russian Scientific Foundation (\#14-14-00262), the immunocytochemical and CLSM investigations were done with support by the Russian Foundation of Basic Research (\#14-04-32176 mol_a), and the processing of the paper was supported by the Russian Scientific Foundation (\#14-50-00029). AK is supported by the Lise-Meitner-Programme of the Austrian Science Fund (FWF) (M-1523-B19).

\section{Author details}

${ }^{1}$ Department of Invertebrate Zoology, Lomonosov Moscow State University, Leninskie Gory 1-12, 119234 Moscow, Russia. ${ }^{2}$ Department of Integrative Zoology, University of Vienna, Althanstraße 14, A-1090 Vienna, Austria.

Received: 5 September 2015 Accepted: 15 January 2016

Published online: 08 February 2016

\section{References}

1. Phillips Dales R. The feeding mechanism and structure of the gut of Owenia fusiformis delle Chiaje. J Mar Biol Assoc United Kingdom. 1957;36:81-9.

2. Villalobos-Guerrero T. Oweniidae Rioja, 1917. In: de León-Gonzalez JA, Bastida-Zabala JR C-P LF, García-Garza ME, Peña-Rivera AS-VS, editors. Poliquetos (Annelida Polychaeta) México y América Trop. Monterrey: V S-W; 2009. p. 391-402.

3. Capa M, Parapar J, Hutchings P. Phylogeny of Oweniidae (Polychaeta) based on morphological data and taxonomic revision of Australian fauna. Zool J Linn Soc. 2012;166:236-78.

4. Smart TI, Von Dassow G. Unusual development of the mitraria larva in the polychaete Owenia collaris. Biol Bull. 2009;217:253-68.

5. Wilson D. On the mitraria larva of Owenia fusiformis Delle Chiaje. Philos Trans R Soc London, Ser B. 1932;221:231-334.

6. Smith PR, Ruppert EE, Gardiner SL. A Deuterostome-Like Nephridium in the Mitraria Larva of Owenia fusiformis (Polychaeta, Annelida). Biol Bull. 1987;172:315.

7. Nielsen C. Animal Evolution. Oxford: Uni; 2012

8. Westheide W. The direction of evolution within the Polychaeta. J Nat Hist. 1997:31:1-15.

9. Gardiner SL. Fine Structure of the Ciliated Epidermis on the Tentacles of Owenia fusiformis (Polychaeta, Oweniidae). Zoomorphologie. 1978:91:37-48.

10. Hausen $\mathrm{H}$. Comparative structure of the epidermis in polychaetes (Annelida). Hydrobiologia. 2005;535-536:25-35.

11. Lagutenko Y. Synaptic terminations on basal lamina of epidermis of oweniids (Polychaeta, Oweniidae). Proc Acad Sci USSR. 1987;296:1477-9.

12. Lagutenko $Y$. The ultrastructure of synapses in the primitive intraepidermal nervous system of Myriochele oculata Zachs (Polychaeta, Oweniidae). Tsitologiya. 1993;35:27-31.

13. Liwanow N, Porfirjewa N. Die Organisation der Pogonophoren und deren Beziehungen zu den Polychäten. Biol Zent BI. 1967;86:177-204.

14. Gilson G. Cellules musculo-glandulaires paroi du corps et fonction excrétoire de l'Owenia. Cellule 1898;87-108 XIV.

15. Watson T. On the structure and habits of the Polychaetae of the family Ammocharidae. J Linn Soc. 1901;28:230-60.

16. Bubko OV. On the systematic position of Oweniidae and Archiannelida (Annelida). Zool Zhurnal. 1973;52:1286-96. 
17. Eeckhaut I, McHugh D, Mardulyn P, Tiedemann R, Monteyne D, Jangoux M, et al. Myzostomida: a link between trochozoans and flatworms? Proc Biol Sci. 2000;267:1383-92.

18. Rousset V, Rouse GW, Siddall ME, Tillier A, Pleijel F. Cladistics 18S rRNA, $28 \mathrm{~S}$ rRNA and morphological data. Cladistics. 2004;20:518-33.

19. Struck TH, Schult N, Kusen T, Hickman E, Bleidorn C, McHugh D, et al. Annelid phylogeny and the status of Sipuncula and Echiura. BMC Evol Biol. 2007;7:57.

20. Capa M, Hutchings P, Aguado M, Bott N. Phylogeny of Sabellidae (Annelida) and relationships with other taxa inferred from morphology and multiple genes. Cladistics. 2011;27:447-557.

21. Meyer K, Bartolomaeus T. Ultrastructure and formation of the hooked setae in Owenia fusiformis delle Chiaje, 1842 : implications for annelid phylogeny. Can J Zool. 1996;74(Bartolomaeus 1994):2143-54

22. Rouse GW, Fauchald K. Cladistics and polychaetes. Zool Scr. 1997;26:139-204.

23. Bleidorn C, Vogt L, Bartolomaeus T. A contribution to sedentary polychaete phylogeny using 18S rRNA sequence data. J Zool Syst Evol Res. 2003;41:186-95.

24. Hall K, Hutchings $P$, Colgan D. Further phylogenetic studies of the Polychaeta using 18S rDNA sequence data. J Mar Biol Ass UK. 2004;84:949-60.

25. Struck T, Nesnidal M, Purschke G, Halanych K. Detecting possibly saturated positions in 185 and 285 sequences and their influence on phylogenetic reconstruction of Annelida (Lophotrochozoa). Mol Phylogenetics and Evol. 2008;48:628-45.

26. Colgan $D$, Hutchings $P$, Braune M. A multigene framework for polychaete phylogenetic studies. Org Divers Evol. 2006;6:220-35.

27. Zrzavý J, Ríha P, Piálek L, Janouskovec J. Phylogeny of Annelida (Lophotrochozoa): total-evidence analysis of morphology and six genes. BMC Evol Biol. 2009;9:189.

28. Struck TH, Paul C, Hill N, Hartmann S, Hosel C, Kube M, et al. Phylogenomic analyses unravel annelid evolution. Nature. 2011;471:95-8.

29. Weigert A, Helm C, Meyer M, Nickel B, Arendt D, Hausdorf B, et al. Illuminating the base of the annelid tree using transcriptomics. Mol Biol Evol. 2014;31:1391-401.

30. Struck TH, Golombek A, Weigert A, Franke FA, Westheide W, Purschke G, et al. The Evolution of Annelids Reveals Two Adaptive Routes to the Interstitial Realm. Curr Biol. 2015;25:1993-1999.

31. Andrade SCS, Novo M, Kawauchi GY, Worsaae K, Pleijel F, Giribet G, et al. Articulating " archiannelids ": Phylogenomics and annelid relationships, with emphasis on meiofaunal taxa. Mol Biol Evol. 2015;32:2860-2875.

32. Laumer CE, Bekkouche N, Kerbl A, Goetz F, Neves RC, Sørensen MV, et al. Spiralian phylogeny informs the evolution of microscopic lineages. Curr Biol. 2015;25:1-6.

33. McIntosh W. On the nervous system and other points in the structure of Owenia and Myriochele. Ann Mag Nat Hist, Ser 8. 1917;19:233-65.

34. Bubko O, Minichev Y. Nervous system of Oweniidae (Polychaeta). Zool zhurnal. 1972;51:1288-99.

35. Coulon J, Bessone R. Cell and tissue autoradiographic detection of indolamine and catecholamine neurons in the nervous system of owenia fusiformis (polychaeta, annelida ). Cell Tissue Res. 1979;198:95-104.

36. Lagutenko Y. Nerve plexus of Myriochele oculata Zachs (Polychaeta, Oweniidae) and its evolutionary significance. Proc Acad Sci USSR. 1985:281:214-7.

37. Lagutenko Y. Neuropil structure of the abdominal trunk in the Oweniidae (Polychaeta). Arkh Anat Gistol Embriol. 1986:90:25-33.

38. Parapar J. Revision of five species referred to Myriochele and Galathowenia (Polychaeta: Oweniidae) from the Antarctic Seas based upon type material. Proc Biol Soc Washingt. 2001;114:403-13.

39. Von DR. 2. Anatomie von Owenia filiformis. - Wien. 22 pp. In: Beiträge zur feineren Anat der Polychaeten Zweites $\mathrm{H}$ Anat von Owenia fusiformis delle Chiaje. Wien: C. Gerold; 1885. p. 1-22.

40. Hessling R, Westheide W. Are Echiura derived from a segmented ancestor? Immunohistochemical analysis of the nervous system in developmental stages of Bonellia viridis. J Morphol. 2002;252:100-13.

41. Orrhage L, Müller MCM. Morphology of the nervous system of Polychaeta (Annelida). Hydrobiologia. 2005;535-536:79-111.

42. Wanninger A, Koop D, Bromham L, Noonan E, Degnan BM. Nervous and muscle system development in Phascolion strombus (Sipuncula). Dev Genes Evol. 2005;215:509-18.

43. Bullock T. Annelida, vol 1. In: Bullock T, Horridge G, editors. Struct Funct Nerv Syst Invertebr. San Francisco: W. H. Free; 1965. p. 661-789.

44. Holland ND. Early central nervous system evolution: an era of skin brains? Nat Rev Neurosci. 2003:4:617-27.

45. Purschke G, Purschke G. On the ground pattern of Annelida. Org Divers Evol. 2002;2(November 2001):181-96.
46. Lehmacher C, Fiege D, Purschke G. Immunohistochemical and ultrastructural analysis of the muscular and nervous systems in the interstitial polychaete Polygordius appendiculatus (Annelida). Zoomorphology. 2014;133:21-41.

47. Jones ML. On the morphology, feeding, and behavior of Magelona sp. Biol Bull. 1968;134:272-97.

48. Martin N, Anctil M. The Nervous System of the Tube-Worm Chaetopterus variopedatus (Polychaeta). J Morph. 1984;181:161-73.

49. Richter S, Loesel R, Purschke G, Schmidt-rhaesa A, Scholtz G, Stach T, et al. Invertebrate neurophylogeny: suggested terms and definitions for a neuroanatomical glossary. Front Zool. 2010;7:1-49.

50. Pilger JF. Echiura. In: Harrison F, editor. Onychophora, Chilopoda, Lesser Protostomata Microsc Anat Invertebr vol 12. New York: Wiley-Liss; 1993. p. $185-236$.

51. Hessling R. Novel aspects of the nervous system of Bonellia viridis (Echiura) revealed by the combination of immunohistochemistry, confocal laserscanning microscopy and three-dimensional reconstruction. Hydrobiologia. 2003;496:225-239

52. Hessling R. Metameric organisation of the nervous system in developmental stages of Urechis caupo (Echiura) and its phylogenetic implications. Zoomorphology. 2002:121:221-34.

53. Müller MCM. Polychaete nervous systems: ground pattern and variationsCLS microscopy and the importance of novel characteristics in phylogenetic analysis. Integr Comp Biol. 2006;46:125-33.

54. Wells G. The proboscis apparatus of Arenicola. J Mar Biol Ass UK. 1952;XXXI:1-28.

55. Pilgrim M. The anatomy and histology of the nervous system and excretory system of the maldanid polychaetes Clymenella torqua and Euclymene oerstedi. J Morph. 1978:155:311-26.

56. Purschke G. Structure of the prostomial appendages and the central nervous system in Protodrilida (Polychaeta). Zoomorphology. 1993;113:1-20.

57. Purschke G. Ultrastructure of nuchal organs in poly- chaetes (Annelida) - new results and review. Acta Zool. 1997:78:123-43.

58. Purschke $G$, Jouin-Toulmond C. Ultrastructure of presumed ocelli in Parenterodrilus taenioides (Polychaeta, Protodrilidae) and their phylogenetic significance. Acta Zool. 1993;74:247-56.

59. Purschke $G$, Jouin-Toulmond C. Ultrastructure of sense organs and central nervous system in Parenterodrilus taenioides and their phylogenetic significance in the taxon Protodrilida (Annelida, Polychaeta). Mem Mus Natn Hist Nat. 1994;162:119-28.

60. Wilkens V, Purschke G. Central nervous system and sense organs, with special reference to photoreceptor-like sensory elements, in Polygordius appendiculatus (Annelida), an interstitial polychaete with uncertain phylogenetic affinities. Invertebr Biol. 2009;128:46-64.

61. Fofanova EG, Nezlin LP, Voronezhskaya EE. Ciliary and nervous structures in juvenile females of the annelid Dinophilus gyrociliatus (O. Schmidt, 1848) (Annelida: Polychaeta). Russ J Mar Biol. 2014;40:43-52.

62. Fauchald K, Jumars PA. The diet of worms: a study of polychaete feeding guilds. In Ocean Mar Biol Ann Rev. Volume 17. Aberdeen U. Edited by Barnes M. Aberdeen University Press; 1979:193-284.

63. Ivanov AV. Fauna of the USSR, New Series. Academy of. Volume 75. Moscow: Leningrad; 1960.

64. Van der Land J, Norrevang A. Structure and Relationships of Lamellibrachia (Annelida, Vestimentifera). In: Det K Danske Vidensk Selsk Biol Skr. 1977.

65. Bubko O, Minichev Y. Nervous system of nereilinum murmanicum ivanov and taxonomic status of pogonophora. Zool zhurnal. 1977:56:1277-87.

66. Malakhov V, Popelyaev I, Galkin S. Microscopic anatomy of Ridgeia phaeophiale Jones, 1985 (Pogonophora, Vestimentifera) and the problem of the position of Vestimentifera in the system of animal kingdom. 2. Integument, nerve system, connective tissue, musculature. Biol Morya. 1996:22:139-47.

67. Worsaae K, Rouse GW. The simplicity of males: dwarf males of four species of Osedax (Siboglinidae; Annelida) investigated by confocal laser scanning microscopy. J Morphol. 2010;271:127-42.

68. Karaseva NP, Malakhov W, Galkin SV. The morphology and anatomy of the vestimentiferan worm Oasisia alvinae Jones, 1985 (Annelida: Siboglinidae). II. Integument, nervous system and musculature. Russ J Mar Biol. 2012:38:10-21.

69. Fauchald K. The polychaete worms: definitions and keys to the orders, families and genera. Nat Hist Museum Los Angeles County, Sci Ser. 1977:28:1-188.

70. Petti MAV, Nonato EF, Bromberg S, Gheller PF, Paiva PC, Corbisier TN. On the taxonomy of Apistobranchus species (Polychaeta: Apistobranchidae) from the Antarctic. Zootaxa. 2007;1440:51-9. 
71. Purschke G. Sense organs in polychaetes (Annelida). Hydrobiologia. 2005;535-536:53-78.

72. Lindsay SM, Jackson JL, Forest DL. Morphology of anterior regeneration in two spionid polychaete species: implications for feeding efficiency. Invertebr Biol. 2008;127:65-79.

73. Santer RM, Laverack MS. Sensory innervation of the tentacles of the polychaete, Sabella pavonina. Zeitschrift f??r Zellforsch und mikroskopische Anat. 1971;122:160-71.

74. Southward EC. Pogonophora. In: Harrison F, Westfall J, editors. Microsc Anat Invertebr, Vol 12 Onychophora, Chilopoda, Lesser Protostomata. New York: Wiley-Liss; 1993. p. 327-69.

75. Hess WN. Nervous system of the earthworm, Lumbricus terrestris L. J Morphol. 1925:40:235-59.

76. Hessling R, Westheide W. CLSM analysis of development and structure of the central nervous system of Enchytraeus crypticus ("Oligochaeta", Enchytraeidae). Zoomorphology. 1999;1 19:37-47.

77. Hessling R, Müller MC, Westheide W. CLSM analysis of serotoninimmunoreactive neurons in the central nervous system of Nais variabilis, Slavina appendiculata and Stylaria lacustris (Oligochaeta: Naididae). Hydrobiologia. 1999;406:223-33.

78. Zattara EE, Bely AE. Fine taxonomic sampling of nervous systems within Naididae (Annelida: Clitellata) reveals evolutionary lability and revised homologies of annelid neural components. Front Zool 2015, 12.

79. Müller MCM. Nerve development, growth and differentiation during regeneration in Enchytraeus fragmentosus and Stylaria lacustris (Oligochaeta) Dev Growth Differ. 2004:46:471-8.

80. Hermans CO. The systematic position of the archiannelida. Syst Zool. 1969;18:85-102.

81. Westheide W. Progenesis as a principle in meiofauna evolution. J Nat Hist. 1987:21:843-54

82. Worsaae K, Kristensen RM. Evolution of interstitial Polychaeta (Annelida). Hydrobiologia. 2005;535:319-40.

83. Eichinger I, Hourdez S, Bright M. Morphology, microanatomy and sequence data of Sclerolinum contortum (Siboglindae, Annelida) of the Gulf of Mexico. Org Divers Evol. 2013;13:311-29.

84. Jones M, Gardiner S. Evidence for a transient di gestive tract in Vestimentifera. Proc Biol Soc Wash. 1988;101:423-33.

85. Miyamoto N, Shinozaki A, Fujiwara Y. Neuroanatomy of the vestimentiferan tubeworm Lamellibrachia satsuma provides insights into the evolution of the polychaete nervous system. PLoS One. 2013;8:e55151.

86. Schlawny A, Hamann T, Muller M, Pfannenstiel H-D. The catecholaminergic system of an annelid (Ophryotrocha puerilis, Polychaeta). Cell Tissue Res. 1991;265:175-84.

87. Starunov W, Lavrova OB. The structure of the nervous system and muscles of the pygidium in the polychaete Alitta virens (Nereididae). Dokl Biol Sci. 2013:451:235-7.

88. Starunov W, Dray N, Belikova EV, Kerner P, Vervoort M, Balavoine G. A metameric origin for the annelid pygidium? BMC Evol Biol. 2015;15:25.

89. Rodriguez J, Deinhard F. Preparation of a semipermanent mounting medium for fluorescent antibody studies. Virology. 1960;12:316-7.

\section{Submit your next manuscript to BioMed Central and we will help you at every step:}

- We accept pre-submission inquiries

- Our selector tool helps you to find the most relevant journal

- We provide round the clock customer support

- Convenient online submission

- Thorough peer review

- Inclusion in PubMed and all major indexing services

- Maximum visibility for your research

Submit your manuscript at www.biomedcentral.com/submit
Biomed Central 